\title{
実験的腎動脈狭窄腎における組織学的研究
}

\section{一 旁糸球体装置を中心として 一}

\author{
金沢大学医学部泌尿器科学教室 岡 野 慎 一
(主任: 黒田教授)
}

\section{A HISTOLOGIC STUDY OF THE KIDNEY WITH EXPERIMENTAL RENAL ARTERY STENOSIS: WITH SPECIAL REFERENCE TO THE JUXTAGLOMERULAR APPARATUS}

\author{
Shinichi Okano \\ From the Department of Urology, School of Medicine, Kanazawa University \\ (Director: Prof. K. Kuroda)
}

1) A histologic study of the kidney, especially the juxtaglomerular apparatus (J.G.A.), was made in 47 rabbits with unilateral stenosis of the renal artery and in 13 control rabbits. Relationship between the degree of constriction and the time relation of histologic changes was investigated.

2) Hypertension was produced in $64 \%$ of moderately, $38 \%$ of lightly, and $24 \%$ of highly constricted groups. Namely moderate constriction produced hypertension on the highest percentage.

3) The injury of tissues increased in proportion to the degree of constriction. It first manifested itself in renal tubules and then glomeruli and interstitial tissues. Changes in the vascular system appeared later. No significant relationship was observed between the development of hypertension and the histologic changes except J.G.A.

4) J.G.A. itself suffered injury by high constriction and lost its function.

5) It was observed how J.G.A. respond following the constriction and concluded that J.G.A. respond in a manner expected of a secretory gland. In addition it was made clear that J.G.I. is able to be applied after one week.

6) The author devised an index of juxtaglomerular apparatus (I.J.G.A.) in order to evaluate hypertrophy and hyperplasia of J.G. cells and demonstrated its usefulness.

\section{I. 緒 言}

腎と高血圧との関連は，古くから注目されていたが， 1934年 Goldblatt et $\mathrm{al}^{11}$. が大で腎動脈狭窄により実験 的高血圧を作成することに初めて成功して以来，かかる 面での研究は飛躍的な発展を遂げ，多種類の方法で高血 圧が作成され，その成因に関しても種々の方面から研究 がなされてきているが，特に renin-angiotensin 系昇圧 機構を中心とする，腎性昇圧因子についての業績が 多 W.

renin が腎のどの部分で産生されるかという点に関し ては Goormaghtigh ${ }^{2)}$ (1939）の報告以来，旁糸球体装

\footnotetext{
*大学院学生
}

置 juxtaglomerular apparatus（以下 JGA と略す）が 殊に関心の的となり，組織学的あるいは組織化学的研究 により，その昇圧機構への関与はかなり確からしいと信 じられるよらになつてきている。

著者は家鬼を用い実験的腎血管性高血圧を作成し, 狭 窄の程度, 血圧, JGA の変化を中心とする組織学的変 化の相互の関係について観察し，若干の知見を得たので 報告する。

\section{II. 文献的考察}

高血圧の成因には古くから種々の説が唱えられていた が，中でも腎との関連については1898年 Tigerstedt and Bergman $^{3)}$ が家鬼腎の食塩抽出液を他の家鬼に注射す ると持続的血圧上昇が起こることを観察し，これをrenin 
と名付けて以来，腎性昇圧因子が 注目を集めるように なつた. 1909年 Janeway ${ }^{4)}$ は大で一側腎の摘除と他側腎 動脈の 1 本の分枝の結䕀により高血圧を産生し， $\mathrm{Cash}^{5)}$ （1924）も腎部分切除と腎動脈の結紮により収縮期圧も 拡張期圧も上昇することを認めたが，まだ多くの注目を 惹くに至らず，1934年 Goldblatt et al。 ${ }^{1)}$ が犬の両側腎 動脈を銀製クリップで狭窄 し 部分的血行障害を 起こさ せ，一様にしか子簡単に持続的高血圧を作成する実験に 成功するに及んで，腎性高血圧症の研究は飛躍的発展を 遂げるに至つた。

実験的腎性高血圧の作成方法についての主なものを列 挙すると，上記の腎動脈を狭窄したり，腎実質を部分的 に切除する方法の他に，腎をセロフアンで包んだり ${ }^{6}$ 。 テープを 8 字型に巻きつけたりりして腎実質を圧迫する

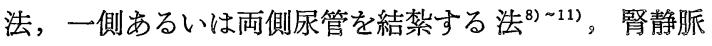
を圧縮し腎うつ血を起こす方法 ${ }^{12)}$ 〜4)，腎にレ線照射す る方法 ${ }^{15)}$, 腎動脈内へ流動パラフイン ${ }^{16)}$ ，ベルリン青 ${ }^{17)}$, 毛髪片 ${ }^{18)}$ などの 異物を注入乙栓塞を起こさせる方法， DOCA や desoxycorticosterone 加食塩水投与による 法 ${ }^{19220)}$, 副腎再生高血圧 ${ }^{21)}$ な゙゙が考案されている. Goldblatt et $\mathrm{al}_{0}{ }^{22)}$ (1936) は更に, 内臓神経を切断しても 腎虚血による高血圧を防止できず，また実験的腎性高血 圧犬の血圧を下降させえないことを立証したが，それに より体液性因子としての腎性昇圧物質 renin が再認識 されるに至つた。 その後1940年 Braun-Menéndez et al。 23), Page et al. ${ }^{24)}$ が潘ぼ同時に renin 自体には昇圧作用 がなく，血浆蛋白に働いて初めて昇圧物質が産生される ことを証明し，この物質が今日 angiotensin と呼ばれ， renin-angsotensin 系昇圧機構は，現在高血圧成因につ いての研究の主流となつている。

renin が腎のどの部位で分泌されるかは誰しもが興味 を持つ問題であるが，初めて腎の JGA と結びつけたの は Goormaghtigh ${ }^{2)}$ であり，実験的高血圧を起こした犬 と家鬼及び人の Comprsesions Syndrome 例で旁系球体 細胞（以下 JG 細胞と略す）が肥大せることを発見し， JG 細胞が renin 分泌という内分泌機能を有しているの ではないかと推測した。

JGA の最初の発見者は杉山 ${ }^{25)}$ (1924）で，マウス腎 の中性赤超生体染色で尿細管の間に特殊な細胞群を発見 し腎小島と命名した。Ruyter ${ }^{26)}$ はやはりマウス腎で糸 球体輸入血管壁に豊富な顆粒を有する類上皮細胞の存在 を記載し，Oberling 27)（1927）が人と家鬼，Okkels ${ }^{28)}$ （1929）が蛙でも発見した。更にその構造の詳細を明ら
かにしたら兄機能面に関して血管収縮物質すなわち renin の内分泌を示唆したのは上記のごとく Goormaght$\mathrm{igh}^{\left.2{ }^{22} 29\right)}$ であり，彼は類上皮細胞の他に輸入血管と輸出 血管の隅角部に Meissner 小体に類似した細胞群を発見 し Goormaghtigh 細胞群と命名している。また Zimm$\mathrm{ermann}^{30)}$ （1933） 性種々の動物でかかる類上皮細胞を 認め Polkissen と呼んだうえ，遠位尿細管が輸入血管に 接する部位の尿細管上皮細胞が密となり細胞の高さも增 して円柱状となつていることを見出し， Macula densa と呼び両者の機能的関連を暗示しているが，Polkissen や Becher ${ }^{31}$ の記載した Paravaskuläre Zellen, 更に Oberling and Hatt ${ }^{32)}$ の言う lacis cell はすべて同種 異名と解される。本邦でる並木ら ${ }^{33)}$ （1943）が稀釈ゲ ンチアナ法による顆粒染色法を報告した後，原田 ${ }^{34)}$-39) （1952）は Masson 氏 Trichrome 染色 Goldner 氏変 法で顆粒を選択的に染色して JGA の構造を詳しく調べ ている。

JGA を構成する主要要素は類上皮細胞すなわち JG 細胞, Goormaghtigh 細胞及び Macula densa であ る. JG 細胞は糸球体輸入血管, 多〈はその糸球体への 入口部付近で血管壁中層にあり, 円形ないし卵円形の細 胞でほ济円形に近い大きな核を有し，顆粒は有している 場合といない場合がある。顆粒が少ない場合には核周囲 に分布するが，多い時は細胞質全体を占める．その発生 起源は輸入血管中膜の平滑筋細胞がその筋線維を失い上 皮細胞様に変化したものと考劣られている40) 42)。顆粒 は種々の染色法で染まるが，現在のところはBowie 染色

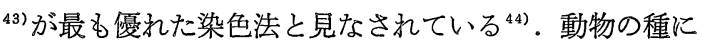
より顆粒の染まり方に非常な差異があり，マウス及びラ ットが最も容易に染色され，家鬼や豚も良く染まるが， 犬や人ではきわめて染色されにくい(45)。江口 ${ }^{46)}$ (1960) は直達血管の発生頻度と比較し, 直達血管の発達が非常 に少ないマウスやラットで JGA が発達し，直達血管の 多く見られる人，牛，馬，鳥や腎門脈や腎動脈副行路の ある両棲類の腎では，証明は不定か困難であると述べて いる。電子顕微鏡的にはこの顆粒は他の内分泌器官，た とえば Langerhans 島の $\beta$ 細胞や下垂体前葉の細胞と類 似の構造を示し，単なる均一な構造体ではなく顆粒の中 に更に内部構造があり小顆粒がしばしば見られる ${ }^{42) 47) 。 ~}$ ついでに JG 細胞についての電子顕微鏡的形態を要約す ると, 細胞はしばしば細長い突起を有し，細胞内には豊 富な RNA 顆粒を有する著明な細胞内網様構造の存在が 特徵的で，核は光学顕微鏡で見ると同様に大きく円形な 
いし卵円形であり，顆粒は限界膜に包まれ均等性の内容 を有する場合と非均等性の内容を有する場合とがある が，そのいずれにも上記のごとく小顆粒が見られること がある ${ }^{32242) 47348)}$. 特に細胞が増生した時に顆粒内の顆粒

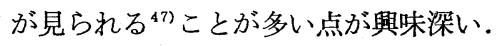

Goormaghtigh 細胞は類上皮細胞の形態に類似してい る. Goormaghtigh は神経成分と考えたが, 電子顕微鏡 的に神経構造に類似していないことが明らかにされてお

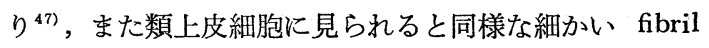
の束が細胞質内に時々存在し, 概して無顆粒であるが僅 かに顆粒を有する場合もあることから，JG 細胞と同様 に平滑筋由来と見なされ (2) 47) 49), JG 細胞の活溌な分泌 活動を必要とする場合にはこの細胞が JG 細胞に転化す る，すなわら JG 細胞の前駆体であると考兄られている 32) 42) 50).

Macula densa は前述のごとく遠位尿細管が糸球体へ 最も近接する部位にあり，輸出入血管に接する側の尿細 管上皮細胞が幅が狭くなり丈が著明に増し密に連なるた めに光学顕微鏡的に容易飞識別されるが，最近の電子顕 微鏡的研究により興味深い所見が得られている。すなわ ち Macula densa が他の尿細管細胞と異なる点は, 細 胞の基底膜の数が少なく，隣接する JG 細胞や Goormaghtigh 細胞と指状の突起を出しあつて接触して和り, ゴルジ系も核より基底側に位置していることなどである 32) 42) 47) 51) 52).

JG 細胞の顆粒化の度合が Hartroft and Hartrof $\mathrm{t}^{53)}$ （1953）の考案した旁系球体顆粒化指数 (Juxtaglomerular Granulation Index, 以下 JGI と略す) といら半定 量的単位を用いて表わすことが可能になつてから JGA の研究は格段の進歩を遂げた。 JG 細胞と renin との 関連を推測した Goormaghtigh の観察は続いて Dunihue and Candon ${ }^{54)}$ (1940) が家鬼を使用した実験的高 血圧症で，Graef ${ }^{55)}$ (1943) が人の腎性高血圧症で確認 しているが, renin が JGA で産生されるとする証明は 間接的方法によるものが多く， Tobian ${ }^{56) 57)}$ (1959) は Goldblatt 型高血圧ラットで腎抽出液の昇圧活性を測定, renin と JGI の変化が比例することを見出し， Pitcock et al $^{58759)}$. (1959), Janacek ${ }^{60)}$ (1960), Fisher et al ${ }^{61)}$ （1965）は, 低食塩食や高食塩食摂取ラットで, Newma$\mathrm{rk}^{62)}$ (1959), Kuhn et al ${ }^{63)}$ （1961）は低食塩食を与兄 た大でそれぞれ JGI と renin との相関を明らかにして

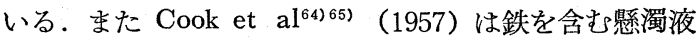
を腎血管系へ注入した後電磁石で糸球体と尿細管を分離
し renin を抽出するとそのほとんどが旁系球体部を含む 系球体にあることを見出し, 更に進んで JGA への局在

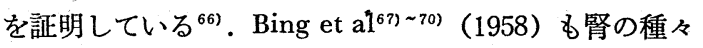
の部の renin 量を分析, renin は旁系球体部にのみ局在 していると報告しているが，血管部分には10～50\%以下 しかなく，残りは Macula densa を含む遠位尿細管部 にあつたという。

また Brown et $\mathrm{al}^{71)}$ (1965) は, 正常家鬼腎に打ける renin の分布を数百枚の連続切片を作つて調べ, JGI と renin 量は顕著な相関を示すことを認めている.

一方 JGA 内の renin の局在を否定する説もあり, Friedman and Kaplan ${ }^{72)}$ 73) (1942) は JGA が未発達の 豚胎児の mesonephros と metanephros $に$ renin が存 在していることや, 酒石酸ソーダを投与して近位尿細管 の壊死を起こした腎で急激な renin 活性の低下を見出し たことにより, renin は尿細管で産生されると主張した が, Yoshimura and Negishi ${ }^{74}$ (1954), Dempoulos et al. ${ }^{75)}$ （1960）によると酒石酸ソーダで近位尿細管を破 壞しても JGI や renin は正常であり, Vikhert and Serebrovskaya ${ }^{76)}$ （1964）も人，家鬼，猫なぞの腎で腎 皮質の表層及び深層のいずれの尿細管にも renin を証 明しえず, renin の局在は局所解剖学的に JG 細胞と一 致していたと述べている.

renin が JG 細胞に局在することを初めて直接的に証 明したのは Edelman and Hartroft $\mathrm{t}^{77)}$ (1961) である. 彼等は蛍光抗体法を使用し, 家鬼之豚の renin 飞対す る大の抗血清を蛍光色素で標識 し正常及び $\mathrm{Na}$ 欠乏の 家鬼と犬， $\mathrm{Na}$ 欠乏のラットの腎の凍結切片を反応させ たところ，家鬼と犬の JG 細胞内に強い蛍光を発するこ とを認め, Hartroft and Hartroft $t^{78)}$ (1964) 西蛍光抗 体法で renin が Macula densa よりも JG 細胞内に局 在していることを示した: 以上より JGA が renin の産 生及び分泌の部位であることは確実で, JGA のどの部 位が主役を演ずるかについては，前記の Bing et al. 以 外に Hess et al..$^{79) ~ 81) ~(1959) ~ F i s h e r ~}{ }^{82)}$ (1961）が酵素 活性の面から Macula densa を重視しているが，JG 細 胞で産生, 分泌されるとする説が一般的である.

JG 細胞顆粒は種々の因子で增减するが，その主なも のは血圧と $\mathrm{Na}$ 及び副腎である.

Dunihue ${ }^{83)}$ （1947）は家鬼に出血性 ショックを起こ すと軽度の場合は顆粒増加は明らかでないが, 高度のシ ヨツクでは顆粒の増加が著明なことを認め, Hartroft and Hartroft ${ }^{84)}$ (1955) はラツトに Naphazolin を注 
射し一時的に高血圧を生じさせると JGI が減少, Hydralazine を注射し低血圧を起こすと JGI が増加する ことを観察し, 血圧の変化が直接の腎への処置なしに JGI の変化をもたらすことを明らかにした. Tobian et al. ${ }^{85)}$ (1959) は, 腎虚血を起こさぬよう注意しながらラ ツトの一側腎を遊離し種々の圧で腎動脈注入実験を行な つたところ高圧では JGI は減少, 低圧では JGI が増 加することをみ, 他方高 $\mathrm{Na}$ 濃度の血液を正常血圧で注 入しても JGI には変化が見られなかつた. 人でも Goormaghtigh $^{86)}$ (1947), Des Prez ${ }^{40)}$ が腎血管性高血圧 症, 急性系球体腎炎, 子痹, 悪性高血圧症などで JG 細 胞顆粒を認めたのをはじめ, 多くの報告がある.

Dunihue and Robertson ${ }^{87)}$ は1949年副腎を摘除した 猫で JG 細胞が肥大増生し顆粒も増加していることを発 見し，その原因を血圧下降に帰したが，Hartroft and Hartrof $\mathrm{t}^{53)}$ は尿中の Na濃度低下が原因ではないかと考 え, ラットにそれぞれ, 高, 正常, 低 $\mathrm{Na}$ 食の投与実験 を行なつたところ，予想通り血圧に著明な変化がなくて も Na 過剩で JGI が減少, Na 制限で JGI が増加し た. JGI と Na の深い関係はその他の研究者の実験成 績からも明らかである ${ }^{88) ~ 911}$. また Pitcock and Hartr-

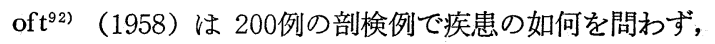
生前に低 Na 血症を有した例では JG 細胞の増生と高顆 粒化を伴い両者間に有意義な関係を認めている.

副腎との関連については Hartroft ${ }^{84) 93)}$ らは JGI と 副腎皮質球状帯の $\log$ 值が高度に有意義な比例関係を有 することを発見し, 血清 $\mathrm{Na}$ と JGI と球状帯間の関係 を明らかにし，続いて Fisher and Klein ${ }^{94)}$ (1963) も その実験成績を支持している。.Torikai95)（1964）は続 発性アルドステロン症や腎動脈狭窄による高血圧患者の 腎生検標本で JGI と患者の尿中 aldosterone 量との正 の相関関係を明らかにしている. その他 Marks et $\mathrm{al}^{96)}$ （1960）は下垂体摘除術後に JG 細胞の顆粒度が減少し たとしているが，JG 細胞は下垂体の影響をこうむらな いとする説が一般的である.

JGA を刺激する因子として血圧と Na のいずれの方 を重視するかは，JGA を圧受容体とみるか化学受容体

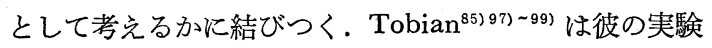
成績から JG 細胞がその位置的関係により輸入血管の伸 展刺激に応ずるとし圧受容体説を強く主張し，Skinner

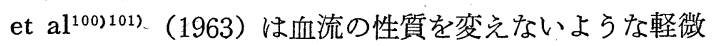
な圧の下降でも renin 遊離が起こること, Shipley and Study $^{1022}$ (1951), Stuhl ${ }^{103)}$ （1964） は輸入小動脈壁の
緊張の変化に影響される腎内自律調節機構の証明, Tribe and Heptinstall ${ }^{104)}(1965)$ はラットで尿細管の萎縮を 起こすか，系球体と尿細管の連絡を絶つた上で両側副腎 摘除術を施行すると，正常組織でも傷つけられた組織で も JGI の著明な増加が見られたことから圧受容体説を 支持している。一方 Hartroft and Hathway ${ }^{93)}$ は Na 欠乏食と正常 $\mathrm{Na}$ 食ラツトにそれぞれピーナツツ油と pitressin のピーナツツ油溶液を注射したところ， Na 欠 そラットと正常 Na 食ラットとの間に JGI の有意義な 差異を見たが, pitressin 注射群とピーナツツ油注射群に はほとんど差異が見られなかつたことから Na が圧より も重要な因子であるとし， Fisher et al. ${ }^{61)} も$ JGI や renin は正常 $\mathrm{Na}$ 食の一側腎摘他側腎動脈狭窄による 高血圧ラットでは正常, $\mathrm{Na}$ 欠乏食ラットでは增加, 高 $\mathrm{Na}$ 食ラットでは減少したことから Na の方を重視して いる.

以上のごとく実験的腎性高血圧症に括ける JG 細胞顆 粒の変化は多くの研究者によつて報告されているが, 特 に一側腎動脈狭窄で両側腎の JGI を比較研究した実験 としては，下記のものがよく知られている。すなわち Hartrof $\mathrm{t}^{105}$ (1957) はラットの一側腎動脈を狭窄して高血 圧を作成し，狭窄腎では顆粒が多いものから正常程度に 存在するものまで種々見られるが, 高血圧の程度とは関 係なく，無処置腎では減少し血圧が高い例洼ど JGI の 減少度が強く, 両者間に逆比例関係が存在することを認 め，また腎の 8 字型結禁による高血圧ラットでは虚血に よる变化が強い部に JG 細胞の増生と顆粒増加が, 比較 的正常な部位では顆粒減少が見られたと報告している. Tobian $^{106)}$ （1958）はやはり一側腎動脈狭窄による高血 圧ラットで JGI を調べ, 狭窄腎では約 2 倍に増加し， 無処置腎では事実上顆粒が消失するが， 7 週後に狭窄腎 を摘除すると無処置腎の顆粒は再び出現, 血圧も正常化 することを認めた。をた一側腎動脈狭窄によつて顆粒が 消失した無処置腎の腎動脈をも狭窄すると再び顆粒が出 現すること，及び一側腎動脈狭窄より 6 力月後に狭窄腎 を摘除すると血圧が正常化した例では無処置腎の JGI は幾分正常值に近づくが，高血圧が治癒しない例では回 復をみないことも報告している ${ }^{88)}$.

JG 細胞の機能, JGA の機能の克進や低下を形態学 的に表現しようとする試みは色々となされている. 大城 107) 111)（1943）は腎小島に関する研究之題する一連の論 文で, ラットやマウスの実験的糸球体腎炎や饑飢時に拈 いて腎小島のこうむる影響を報告しているが,その際 JG 
細胞数を表わす方法として50個の糸球体を計上，その中 飞出現する全 JG 細胞数の算術平均値を求めた．細胞数 の增減から JGA の活動を知らうとする方法は他に Turgeon and Sommers ${ }^{112) 113}$ ) (1960) の Juxtaglomerular Cell Count (JGCC) なる単位がある. 彼等は Bowie 染色をを用いて25個の糸球体の全 JG 細胞数を測定し JGCC としたが, Goldblatt 型腎で JGCC の著明な増 加を認め， しかも術前の高血圧の期間の長さ己 JGCC とは逆比例の関係が成立することを発見し; 偏腎性高血 圧症では JGCC の増加せる例注ど腎摘による治癒率が 高く, また糸球体腎炎の初期, 本態性高血圧, 褐色細胞 腫では軽度の増加を見たが，悪性高血圧や慢性系球体 腎炎では JGCC の増加が見られなかつたとしている。 Crocker et al. ${ }^{144}$ (1962), Boughton and Sommers ${ }^{115}$ )

(1963) もとれぞれ25例及び10例の腎摘除術を施行した 偏腎性高血圧例で JGCC を調べ，外科的に治癒しうる 腎性高血圧例に JGCC の有意義な増加が認められるこ とから，高血圧患者のらち外科手術の適応となる例を選 択するのに有意義な方法であると結論している.

JG 細胞の顆粒の増減より JGA の活動を推測する方 法には前述の JGI があり, 顆粒化の程度を 4 段階に分 け JGI を算出するが，その方法の詳細については実験 方法の項に記述する。織田 ${ }^{116)}$ (1955) はゲンチアナ紫染 色で JGI を求めているが，一般に JGI は Bowie 染 色によるものを意味し，前述のごとく JGI を用いて多 くの研究報告がなされている. 一方 Itskovitz et al. ${ }^{117}$ （1963）は腎生検で得られた40例の高血圧患者の組織の Bowie 染色を行ない，JG 細胞飞顆粒を有していない 糸球体には 0 , 顆粒の存在が疑わしい場合は 0.5 , 明ら かであるが少ない場合は 1 , 明らかに顆粒を有する時は 5, 非常に著明な時には10を乗じて算定した全糸球体につ いての平均值を求め, juxtaglomerular activity という 単位で表わし，高值を示す例活ど手術による治癒の可能 性が高いと述べている。

以上特に JGA についての文献的考察を行なつたが， JGA 以外の腎組織についても高血圧との関連において 種々の検索がなされている. Goldblatt ${ }^{118)}$ （1938）は腎 動脈狭窄犬で諸臟器の血管病変を中心に検索し胃, 腸, 膵, 脾, 胆䨞, 膀脂などに細動脈壁の壊死性病変を見た が腎には見られなかつたとし,Wilson and Pickering ${ }^{119}$ （1937）は腎動脈狭窄家鬼で血圧上昇の著明な例に胃腸 の他, 副腎, 肝, 心, 網膜飞も細動脈壊死々内膜肥厚を 認めたが，細小血管の壞死については桂 ${ }^{120)}$ (1957）も実
験例 110例中30例に脳の血管壊死を発見し，腎では 143 例中僅かに 3 例にのみ認めたにすぎないと述べている. また亀山 ${ }^{121)}$ (1958）も，血管系にはうつ血と小出血を見 るのみで細小動脈の壊死はきわめてまれであつたとして いる. Goldblatt 型高血圧腎の組織学的変化については その後も報告がなされているが122) 126)，腎実質の変化 を系統的に観察した報告が行なわれるようになつたのは 最近になつてからである ${ }^{127) ~ 133)}$. 大島, 栗本 ${ }^{125)}$ は特に 尿細管の変化に注目しているが，血圧上昇度と細尿管の 形態学的変化との間には関連性を認めなかつたと述べて 怙り，前川 ${ }^{130)}$ は大で種々の方法によつて高血圧を作 成, Goldblatt 型腎では糸球体の肥大または萎縮や核の 濃縮, Bowman 露の肥厚户 hyalin 沈着, 糸球体周囲 の細胞浸潤, 尿細管に予ける種々の程度の变性, 血管系 には細小動脈の内膜肥厚や内腔の閉塞，ある例では細 小動脈中膜の細胞增殖，間質では細胞浸潤や結合織の増 殖を見出し，腎，心，血管，とりわけ腎の変化は高血圧 と密接な関係を有するが，血圧上昇と腎組織障害の程度 には平行関係は見られず，腎の組織学的変化は高血圧の 原因としては考兄られないと結論している。彼等はまた Page 型高血圧腎でもほぼ同様の組織学的所見を得たと 述べている. 他方松永 ${ }^{131}$ は家鬼で Goldblatt 型高血圧 を作成し，腎実質特に尿細管上皮の壊死，結合織増殖 及びそれに伴う実質組織の消失の程度や拡がりによつて 荒廃度を 4 段階に分けて観察しているが，荒廃度と血圧 上昇度に著明な相関を見出し，ぬた腎細小動液の肥厚と 血圧上昇との間にも密接な関係があつたと報告し，池上 $ら^{1322}$ は処置腎の変化が高度な場合は実質は活とんで壊 死ない乙瘢痕化し，随所に萎縮した尿細管の遺残が見ら れ，系球体も貧血性萎縮に陥り間質性細胞浸潤が明白 で，軽度な場合には糸球体の貧血，萎縮，尿細管の菱縮 は見られるが軽度で間質の細胞浸潤も少なく, 洀痕化は 見られないとしたら光, 血圧立進の程度は腎病変の程度 と比例しないと報告している。すた最近穴戸 ${ }^{133}$ らは成 犬に実験的腎動脈狭窄を施行して観察したところ，処置 後 $6 \sim 7$ 週では糸球体には内皮と mesangium 核増加及 び肥厚, 硝子樣変化ないし荒廃, Bowman 囊には著明 な線維性肥厚と軽い半月体形成, 尿細管には管腔拡大や 上皮細胞の変性脱落を, 間質では細胞浸潤と線維性肥厚 とを認め, 中小血管には内中膜の肥厚や軽度の硝子様変 化, 殊飞輸入動脈壁の肥厚を見, 腎内小動脈の病変が高 血圧の成因になると考えている。かように腎組織, なか んづく細小動脈を中心とする腎内血管系の病変と高血圧 
の成因に関して種々論じられているが，高血圧の病因 となるとする研究者も否定の立場をとる研究者も関心 を寄せているのは事実である。Moritz and Oldt ${ }^{134) 135)}$ （1935）は剖検例で腎細小動液の変化を内膜の増生，中 膜の増生や変性に分類しているが，これらの変化は高血 圧例で97\%に認められたのに比し非高血圧例では $12 \%$ に しか認められなかつたと述へ，また西森 ${ }^{136)}$ （1963）は 副腎再生高血圧々抗腎血清腎炎に由来する高血圧の実験 で，いまだ高血圧が発現せず他の臟器血管にも器質的変 化の出現していない時期に，既に腎の小動脈に血管病変 の見られることを根拠として，腎小動脈の中膜変性を主 体とする病変が高血圧発生にははなはだ重要な意味を有 していると考えている。

\section{III. 実験材料及び方法}

\section{1。予備実験}

家鬼の血圧の測定法には観血的方法と非観血的方法と がある。観血的方法は頝動脈や大腿動脈を使用するが長 期にわたり何回も測定できない欠点があるので，非観血 的方法を採用した。最初は無処置家鬼の血圧測定を試み たが，耳殸中心動脈が収縮し血圧計で拍動を観察できな い家鬼が多く，外的刺激をなるべく少なくするよう努め ても22羽中 6 羽のみ測定しえたにすぎなかつた。可能で あつた 6 例の中でもその後繰り返して測定してみると血 圧の動摇が著しく，差が60 mm Hg 以上なるまで出現し た。

そこで血管神経切断法 ${ }^{137)}$ を採用した。血管神経切断 後直ちに耳殼中心動脈は拡張し血圧測定可能となつた。 計 95 羽に施行し翌日より少なくとも 2 週間以上にわたり 連日血圧測定を行なつた。切断後の血圧の変化は次の 4 型に分けられた.すなわち第 1 は血圧の動摇が少なく10 $\mathrm{mm} H \mathrm{~g}$ 以内のもので大部分の 68 羽が該当し，第 2 は変動が 激しく $10 \mathrm{~mm} H \mathrm{H}$ 以上になるもので 11 羽が該当，第 3 は次第 飞血圧が下降するもので12羽が該当し，5ち 4 羽は測定 不能に陥つた。第 4 は血圧の漸増を示すもので 4 羽が該 当した。腎動脈狭窄実験には以上のうち第 1 の型，すな わち血圧の高低差が $10 \mathrm{~mm} H \mathrm{H}$ 以内の家鬼のみを使用した。

\section{2 。実験材料}

体重 2.4〜 2.8kgの成熟家要60羽を使用した。气のう ち13羽は対照とした。

3。 実験方法

1）前処置及び麻醉

前処置として手術当日は絶食させ，麻酔はエーテル吸 入麻酔によつた。

\section{2）手術法}

左腰部斜切開にて腹膜と仙棘筋を分けるよらにして後 腹膜腔に入り，腹膜を破らぬよう注意しながら腎門部に 達し，左腎動脈を剝離後ほぼ中間の位置で狭窄を作成し た。狭窄方法は高度狭窄群は25ゲージ，中等度及び軽度 狭窄群はそれぞれ21，19ゲージ注射針を腎動脈にそわせ てワイヤーロープで結紮した後注射針を拔去した．テラ マイシン50mgを゙術野に撒布，50mg筋注後狭窄腎を元の位 置に整復し筋膜及び皮膚を縫合した。

3）血圧測定法

福田。川口氏家鬼用血圧計年7 使用した。

4）大動脈撮影法

エーテル麻醉下に 30 番ポリエチンンチユーブを右大腿 動脈より插入，腎動脈分岐部よりやや上に至らしめ， $80 \mathrm{w} / \mathrm{v}$ \%アンギオコンレイ $4 \mathrm{ml}$ を手圧で急速に注入し 連続撮影した。

5）組織学的検查方法

逐時的变化を観察する目的で，処置後24時間，3日， 1 週, 2 週, 1 力月, 更に高度狭窄群では 3 カ月で屠殺 し直ちに両側腎を摘出した。

(i) Bowie 氏染色法

Helly 氏液に 12 時間固定後, 10 分間水洗, 以後型通り の手順でパラフインに包埋， $4 \mu$ 飞薄切し脱パラフィン 後水洗せずにヨードアルコールに10分, 水洗10分，次い で0.25\%ハイポ水に10分, 水洗30分行なら。続いて Bowie 氏染色液に24時間入れアセトンを迅速に通しキシロ ール・クローブ油同比率混合液で切片が薄い青紫色を呈 するまで分別し，キシロールを経てキシロールバルサム に封入する。Bowie 氏染色法により腎実質は淡青色。 赤血球は赤紫色, JG 細胞顆粒は濃青色に染まる。

(ii) JGI の算定

Hartroft and Hartrof t $^{53)}$ の方法に準じ JGA 100個 を数え，有する顆粒の程度によつて，I，II，正度に分 類し，I 度には $1, \mathbb{I}$ 度には 2 ，正度には 4 を乗じてそ の総計をJGI とした。

I 度：核の周囲に顆粒がわずかに散在しているるの

II度：細胞内にかなり顆粒を有しているもの。

亚度：細胞内に多数の顆粒を有しているもの。

JG 細胞顆粒を上記のごとく分類する際に，I度にす

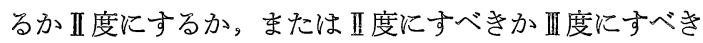
か判定に迷う場合があるが, 長崎大学原医研病理部門西 森教授に教示された基集に従つた。

(iii) IJGA の算定 
100個の糸球体を数える間に出現する JGA 数で表わ した．顆粒がなくとも空胞化ないし分泌細胞様の形態を 示した輸入血管も数えた.

(iv) その他の染色法

ヘマトキシリンエオジン染色, PAS 染色, Masson 氏 Trichrome 染色をホルマリン固定の全標本について 施行した.

\section{IV. 実験成績}

1. 正常及び血管神経切断家鬼の組織学的所見.

血管神経切断による腎組織，殊に JGA への影響を調 べるために無処置家兔 3 羽，血管神経切断後 3 週間の家 鬼 5 羽について組織学的検索を行なつた。まず JGA に ついては，無処置家鬼群の JGI は各26，17，20で平均 21.0，IJGA は各30，23，23で平均25.3であつた. 神経 切断家兔群では JGI が最低17, 最高29で平均 22.3 , IJGA は最低 20 , 最高29で平均25.2であり，両群の間に 全く差異を認めなかつた。 その他，糸球体，尿細管，間 質，血管などにも血管神経切断による影響を全く認めな かつた．以上の成績から本実験に扔いては正常家鬼の JGI は15以上30以下, IJGA は20以上30以下とする.

2. 血圧の変化

狭窄処置施行前 3 日間の血圧を平均し小数点以下を四 捨五入した数值をもつて正常血圧とした. 予備実験第 4 群の正常血圧は最低がNo. 72の63で, 最高がNo. 23の94 であり大多数は65 85の範囲内にあり平均は77.8であつ た。狭窄処置によつて血圧がどの程度上昇すれば高血圧 と認めるかは問題であるが， $20 \mathrm{~mm} H \mathrm{Hg}$ 以上昇した場合に 高血圧例とした. 以下に各群の血圧変動を記載する.

1）短時間群

24時間では前日の手術や麻酔による血圧への影響が考 えられるので，高血圧となつたか否かの判定は避ける が，3 例のうち 2 例はほとんど変化せず，No. 89 の 26 $\mathrm{mm} H \mathrm{~g}$ の上昇を示した. 3 日群では 3 例のらち血圧上昇し た No. 93は術翌日より血圧が上昇した。

2) 軽度狭窄群

この群の狭窄程度を示すために写真18 に No. 75の腎 動脈撮影像を示す. 13例のうち高血圧となつたのは No. $76 ， 74 ， 75 ， 66 ， 53$ の 5 例で，そのらち 2 例は翌日， 2 例は 2 日後， 1 例は 4 日後から血圧上昇が著明となつ た。昇圧程度は第 2 表のごとく最高が No. 66 の3 $\mathrm{mm} H \mathrm{mg}$ であつた。血圧上昇は持続的で激しい変動は示さなかつ た. No. 72 は術翌日から $15 \mathrm{~mm} \mathrm{Hg}$ 程度の上昇を約 2 週間に わたつて持続した。
第 1 表 正常対照群

\begin{tabular}{|c|c|c|c|c|c|c|c|}
\hline 番号 & 処 置 & $\mathrm{J} \mathrm{G} \mathrm{I}$ & 0 度 & I 度 & II 度 & II 度 & I J G A \\
\hline 3 & 無処置 & 26 & 18 & 7 & 4 & 1 & 30 \\
\hline 7 & 無処置 & 20 & 11 & 8 & 2 & 2 & 23 \\
\hline 8 & 無処置 & 17 & 13 & 7 & 1 & 2 & 23 \\
\hline 10 & 神経切断 & 28 & 10 & 4 & 4 & 4 & 22 \\
\hline 12 & " & 29 & 13 & 5 & 8 & 2 & 28 \\
\hline 14 & " & 26 & 18 & 2 & 4 & 4 & 28 \\
\hline 15 & " & 17 & 18 & 1 & 3 & 2 & 24 \\
\hline 19 & " & 25 & 12 & 5 & 2 & 4 & 23 \\
\hline 20 & " & 19 & 12 & 2 & 6 & 3 & 23 \\
\hline 30 & " & 20 & 15 & 6 & 5 & 1 & 27 \\
\hline 40 & " & 24 & 18 & 2 & 5 & 3 & 28 \\
\hline 81 & " & 23 & 16 & 5 & 3 & 3 & 29 \\
\hline 96 & " & 22 & 12 & 2 & 2 & 4 & 20 \\
\hline
\end{tabular}

3）中等度狭窄群

中等度狭窄では写真19に示す程度の狭窄となつた．14 例のうち 1 週間群の 2 例, 2 週間群の 3 例, 1 カ月群の 3 例が高血圧となつた． 8 例とも術翌日から第 4 日の間 に血圧が上昇しはじめ, 多少の動摇はあつても持続的に 高血圧が保持された．非高血圧例とした中で，No.80は 動摇しながらも約 $10 \mathrm{~mm} \mathrm{Hg}$ 血圧上昇を見て拉り，また No. 92 は術後 3 日間は $30 \mathrm{~mm} H \mathrm{H}$ 以上血圧が上昇したが，第 4 日より次第に下降し第 9 日より術前の血圧へ戻つた. No. 82は術後急に血圧が下降，第 5 日以降測定不能とな つた.

4）高度狭窄群

この群の狭窄程度も写真20亿示す.

No. 34，39，45の 3 例だけ高血圧となつたが， 2 例は 翌日から 1 例は第 5 日から血圧上昇が起こつている。こ の群の非高血圧例には中等度狭窄群のNo. 92のような一 時的に $20 \mathrm{~mm} H \mathrm{H}$ 以上の血圧上昇をみた例はないが，No. 21 は約10日間10mm Hg程度の上昇をみている。

以上各群の成績をまとめてみると，軽度狭窄群では13 例中 5 例, 中等度狭窄群では No. 92 も一応高血圧例に入 れると 14 例中 9 例, 高度狭窄群では 13 例中 3 例が高血圧 となつた。

しかし血圧の上昇幅は各群で著明の差異が見られず， 一側腎動脈の狭窄では20〜 30mm Hg程度のことが多い. 最

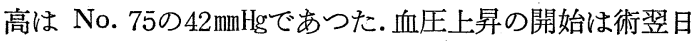
より始まつたものが 6 例，第 2 日 4 例，第 3 日 3 例，第 5 日 1 例で血圧上昇する場合は術後第 $1 \sim 5$ 日で上昇が みられた. 従つて高血圧となつたか否かの判定は術後 1 
第 2 表 狭窄群（腎重量以降の各項上段は無処置側，下段は狭窄側を示す）

\begin{tabular}{|c|c|c|c|c|c|c|c|c|c|c|c|c|}
\hline 番号 & 狭窄度 & 期 間 & $\left|\begin{array}{l}\text { 正常血 } \\
\text { 圧 } \mathrm{mm} H \mathrm{Hg}\end{array}\right|$ & $\begin{array}{c}\text { 最終血生 } \\
\mathrm{mm} H \mathrm{Hg}\end{array}$ & $\begin{array}{l}\text { 上昇幅 } \\
\text { mmHg }\end{array}$ & 腎重量 g & J G I & 0 度 & I 度 & II 度 & III 度 & I J GA \\
\hline \multirow{2}{*}{84} & \multirow{2}{*}{ 中等度 } & \multirow{2}{*}{ 24時間 } & \multirow{2}{*}{90} & \multirow{2}{*}{90} & \multirow{2}{*}{0} & 7.4 & 0 & 22 & 0 & 0 & 0 & 22 \\
\hline & & & & & & 6.5 & 11 & 20 & 1 & 1 & 2 & 24 \\
\hline \multirow{2}{*}{89} & \multirow{2}{*}{$" \prime$} & \multirow{2}{*}{$" \prime$} & \multirow{2}{*}{74} & \multirow{2}{*}{100} & \multirow{2}{*}{26} & 5.4 & 6 & 19 & 2 & 0 & 1 & 22 \\
\hline & & & & & & 5.9 & 14 & 23 & 0 & 1 & 3 & 27 \\
\hline \multirow{2}{*}{91} & \multirow{2}{*}{$" \prime$} & \multirow{2}{*}{$" \prime$} & \multirow{2}{*}{82} & \multirow{2}{*}{88} & \multirow{2}{*}{6} & 7.5 & 3 & 21 & 1 & 1 & 0 & 23 \\
\hline & & & & & & 7.8 & 14 & 19 & 4 & 1 & 2 & 26 \\
\hline \multirow{2}{*}{96} & \multirow{2}{*}{ 高 度 } & & & & & 6.7 & 11 & 21 & 1 & 1 & 2 & 25 \\
\hline & & "I & 83 & 80 & 3 & 6.9 & 12 & 18 & 2 & 1 & 2 & 23 \\
\hline & & & & & & 6.5 & 8 & 21 & 0 & 2 & 1 & 24 \\
\hline 87 & 中等度 & 3 日 & $T 2$ & 60 & -12 & 5.8 & 16 & 15 & 2 & 1 & 3 & 21 \\
\hline & & 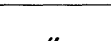 & 81 & $82+>$ & & 6.4 & 6 & 24 & 2 & 2 & 0 & 28 \\
\hline 90 & $" \prime$ & $"$ & 01 & Oo & $Z$ & 6.4 & 15 & 20 & 3 & 2 & 2 & 27 \\
\hline & & & & & & 7.0 & 0 & 20 & 0 & 0 & 0 & 20 \\
\hline 93 & 高 度 & "I & 78 & 105 & 27 & 6.7 & 18 & 20 & 2 & 4 & 2 & 28 \\
\hline 95 & & & 70 & 76 & 6 & 6.7 & 12 & 16 & 2 & 1 & 2 & 21 \\
\hline 00 & 特 仅 & 1 迎 & 10 & 10 & 0 & 6.6 & 10 & 26 & 4 & 1 & 1 & 32 \\
\hline & & & & & & 8.6 & 23 & 21 & 3 & 3 & 3 & 30 \\
\hline 69 & " & "I & 80 & 80 & 2 & 10.8 & 15 & 19 & 3 & 2 & 2 & 26 \\
\hline & & & & & & 6.6 & 13 & 16 & 3 & 1 & 2 & 22 \\
\hline 74 & " & " & 71 & 101 & 30 & 7.0 & 42 & 18 & 4 & 11 & 4 & 37 \\
\hline 76 & 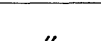 & 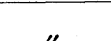 & 74 & 99 & 26 & 9.0 & 17 & 15 & 1 & 2 & 3 & 21 \\
\hline 10 & $"$ & $n$ & 14 & J & 80 & 8.5 & 31 & 23 & 1 & 3 & 6 & 33 \\
\hline & & & & & & 7.1 & 5 & 24 & 1 & 2 & 0 & 27 \\
\hline 56 & " & Z 遍 & 80 & 83 & 3 & 6.8 & 19 & 18 & 1 & 3 & 3 & 25 \\
\hline & & & & & & 6.6 & 7 & 23 & 1 & 1 & 1 & 26 \\
\hline 58 & " & " & 90 & 67 & -23 & 6.2 & 17 & 19 & 3 & 3 & 2 & 27 \\
\hline 75 & 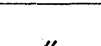 & 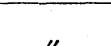 & 84 & 126 & 38 & 6.4 & 0 & 19 & 0 & 0 & 0 & 19 \\
\hline 15 & $"$ & $"$ & 07 & 120 & 00 & 6.3 & 86 & 20 & 2 & 6 & 18 & 46 \\
\hline & & 1 力日 & 71 & 98 & 27 & 7.6 & 0 & 24 & 0 & 0 & 0 & 24 \\
\hline 53 & "I & 1 力 & 11 & 90 & 21 & 7.4 & 41 & 20 & 5 & 2 & 8 & 45 \\
\hline 61 & " & "I & 66 & 73 & 7 & 7.3 & 1 & 25 & 1 & 0 & 0 & 26 \\
\hline & $m$ & & & & 1 & 7.2 & 17 & 21 & 1 & 4 & 2 & 28 \\
\hline 61 & 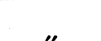 & 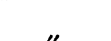 & 92 & 82 & -10 & 6.3 & 11 & 17 & 3 & 2 & 1 & 23 \\
\hline 64 & "I & $" \prime$ & 94 & 04 & -10 & 6.3 & 30 & 17 & 2 & 6 & 4 & 29 \\
\hline & & & & & & 5.7 & 0 & 19 & 0 & 0 & 0 & 19 \\
\hline 66 & " & " & $T 7$ & 110 & 33 & 5.7 & 25 & 23 & 3 & 1 & 5 & 32 \\
\hline & & & & & 11 & 6.7 & 0 & 17 & 0 & 0 & 0 & 17 \\
\hline 72 & " & "I & 73 & 84 & 21 & 6.4 & 15 & 19 & 3 & 2 & 2 & 26 \\
\hline 78 & 11 & 11 & 65 & 74 & 9 & 7.5 & 13 & 17 & 3 & 1 & 2 & 23 \\
\hline 18 & $" 1$ & $" I$ & 00 & 14 & J & 7.7 & 9 & 18 & 5 & 2 & 0 & 25 \\
\hline & 中筀度 & & 68 & 00 & 22 & 7.5 & 0 & 26 & 0 & 0 & 0 & 26 \\
\hline 54 & 中等度 & 1 迥 & 08 & 90 & 24 & 7.5 & 59 & 12 & 9 & 7 & 9 & 37 \\
\hline 55 & 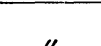 & 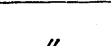 & 84 & 118 & 34 & 7.8 & 9 & 19 & 1 & 2 & 1 & 23 \\
\hline 00 & $"$ & $"$ & 04 & 110 & 34 & 8.2 & 67 & 18 & 5 & 7 & 12 & 42 \\
\hline
\end{tabular}




\begin{tabular}{|c|c|c|c|c|c|c|c|c|c|c|c|c|}
\hline \multirow{2}{*}{67} & \multirow{2}{*}{ " } & \multirow{2}{*}{ " } & \multirow{2}{*}{95} & \multirow{2}{*}{98} & \multirow{2}{*}{3} & 7.2 & 33 & 12 & 3 & 3 & 6 & 24 \\
\hline & & & & & & 7.1 & 44 & 8 & 10 & 3 & 7 & 28 \\
\hline \multirow{2}{*}{88} & \multirow{2}{*}{ " } & \multirow{2}{*}{ " } & \multirow{2}{*}{72} & \multirow{2}{*}{80} & \multirow{2}{*}{8} & 6.5 & 13 & 16 & 5 & 2 & 1 & 24 \\
\hline & & & & & & 5.8 & 18 & 21 & 3 & 1 & 4 & 29 \\
\hline \multirow{2}{*}{82} & \multirow{2}{*}{ " } & \multirow{2}{*}{2 週 } & \multirow{2}{*}{68} & \multirow{2}{*}{ ? } & \multirow{2}{*}{$?$} & 6.6 & 7 & 20 & 1 & 1 & 1 & 23 \\
\hline & & & & & & 6.4 & 30 & 15 & 6 & 4 & 4 & 29 \\
\hline 83 & 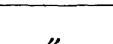 & 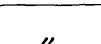 & 72 & 98 & 26 & 7.7 & 0 & 23 & 0 & 0 & 0 & 23 \\
\hline 00 & " & " & 14 & 90 & 40 & 7.6 & 57 & 15 & 3 & 7 & 10 & 35 \\
\hline 85 & 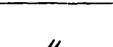 & 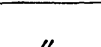 & 79 & 106 & 27 & 5.9 & 0 & 18 & 0 & 0 & 0 & 18 \\
\hline (0) & & & & 100 & 21 & 5.9 & 62 & 16 & 4 & 5 & 12 & 37 \\
\hline 86 & 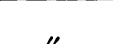 & 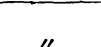 & 72 & 03 & 21 & 7.0 & 0 & 20 & 0 & 0 & 0 & 20 \\
\hline 00 & " & $"$ & 12 & 90 & 21 & 7.0 & 20 & 24 & 2 & 3 & 3 & 32 \\
\hline 99 & "1) & 11 & 84 & 86 & $?$ & 6.3 & 0 & 24 & 0 & 0 & 0 & 24 \\
\hline 92 & & " & 84 & 80 & 4 & 6.3 & 26 & 16 & 4 & 3 & 4 & 27 \\
\hline 63 & 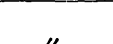 & 1力日 & 67 & 97 & 30 & 6.7 & 0 & 28 & 0 & 0 & 0 & 28 \\
\hline 03 & " & 1 月月 & or & 97 & 30 & 6.5 & 48 & 18 & 9 & 6 & 4 & 37 \\
\hline 68 & " & "I & 73 & 95 & 22 & 7.3 & 0 & 20 & 0 & 0 & 0 & 20 \\
\hline & & & & & 24 & 7.1 & 51 & 13 & 9 & 5 & 8 & 35 \\
\hline 80 & 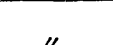 & 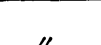 & 101 & 113 & 12 & 7.5 & 0 & 23 & 0 & 0 & 0 & 23 \\
\hline 00 & $"$ & " & 101 & 110 & 14 & 7.0 & 16 & 19 & 8 & 2 & 1 & 30 \\
\hline 94 & II & "11 & 75 & 84 & 9 & 7.2 & 20 & 12 & 4 & 4 & 2 & 22 \\
\hline 84 & $"$ & 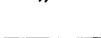 & 10 & x & & 6.9 & 22 & 19 & 6 & 2 & 3 & 30 \\
\hline 05 & 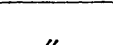 & 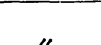 & 74 & 94 & 20 & 6.0 & 0 & 28 & 0 & 0 & 0 & 28 \\
\hline & & " & 14 & $\sqrt{3}$ & 20 & 5.9 & 18 & 25 & 10 & 2 & 1 & 35 \\
\hline 34 & 高 度 & 1 凋 & 68 & 00 & 22 & 7.8 & 68 & 13 & 6 & 3 & 14 & 36 \\
\hline 34 & 㒷 度 & 1 週 & 08 & 90 & 24 & 7.0 & 21 & 21 & 5 & 4 & 2 & 32 \\
\hline 38 & 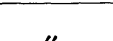 & 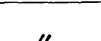 & 76 & 81 & 5 & 6.9 & 26 & 12 & 6 & 4 & 3 & 25 \\
\hline & $"$ & " & 10 & 01 & 0 & 6.7 & 15 & 15 & 3 & 2 & 2 & 22 \\
\hline 39 & 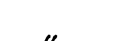 & 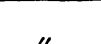 & 79 & 93 & 21 & 6.5 & 31 & 13 & 7 & 5 & 4 & 29 \\
\hline 39 & " & $"$ & 18 & 90 & 21 & 6.5 & 27 & 16 & 3 & 6 & 3 & 28 \\
\hline 22 & 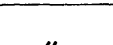 & 2 沺 & 85 & 88 & 3 & 6.4 & 10 & 21 & 0 & 5 & 0 & 24 \\
\hline 20 & $"$ & 4 迥 & ou & 00 & 0 & 5.7 & 0 & 11 & 0 & 0 & 0 & 11 \\
\hline 15 & 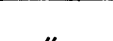 & 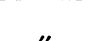 & 74 & 94 & 20 & 8.2 & 25 & 13 & 7 & 5 & 2 & 27 \\
\hline 40 & " & " & 14 & 94 & 20 & 7.8 & 0 & 23 & 0 & 0 & 0 & 23 \\
\hline 46 & 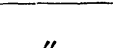 & 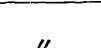 & 70 & 78 & 8 & 6.4 & 40 & 10 & 6 & 7 & 5 & 28 \\
\hline 40 & $" \prime$ & " & & & 0 & 6.6 & 0 & 14 & 0 & 0 & 0 & 14 \\
\hline 21 & 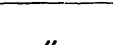 & 1 昌 & 84 & 76 & -8 & 6.5 & 19 & 14 & 1 & 5 & 2 & 23 \\
\hline 21 & " & 1 具 & 84 & 10 & -0 & 4.4 & 0 & 20 & 0 & 0 & 0 & 20 \\
\hline 24 & $\prime \prime$ & "1 & 90 & 93 & 3 & 6.8 & 15 & 20 & 1 & 1 & 3 & 25 \\
\hline & & & & & & 5.0 & 0 & 13 & 0 & 0 & 0 & 13 \\
\hline 29 & 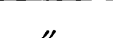 & "1 & 82 & 77 & 5 & 6.7 & 27 & 19 & 1 & 3 & 5 & 28 \\
\hline 20 & $"$ & $"$ & & 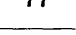 & -5 & 6.0 & 0 & 18 & 0 & 0 & 0 & 18 \\
\hline 31 & " & " & 74 & 79 & 5 & 5.9 & 36 & 20 & 2 & 3 & 7 & 32 \\
\hline & & & & & & 4.7 & 0 & 15 & 0 & 0 & 0 & 15 \\
\hline 32 & " & 3 カ月 & 90 & 76 & -14 & $\frac{6.6}{28}$ & 11 & 20 & 1 & 3 & 2 & 26 \\
\hline 33 & " & 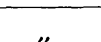 & 88 & & 6 & 6.2 & 19 & 20 & 3 & 3 & 1 & $\begin{array}{r}0 \\
27\end{array}$ \\
\hline & & " & 88 & 94 & 6 & 0.9 & 0 & 0 & 0 & 0 & 0 & 0 \\
\hline 35 & " & " & 86 & 90 & 4 & 7.7 & 46 & 13 & 4 & 3 & 9 & 29 \\
\hline & & & & & & 3.9 & 0 & 9 & 0 & 0 & 0 & 9 \\
\hline
\end{tabular}


第 3 表 短時間群組織像

\begin{tabular}{|c|c|c|c|c|c|c|c|c|c|c|c|c|c|c|c|c|c|c|c|c|}
\hline \multirow{3}{*}{ 番号 } & \multicolumn{3}{|c|}{ 糸 } & \multicolumn{2}{|c|}{ 球 } & \multicolumn{3}{|l|}{ 体 } & \multicolumn{3}{|c|}{ 尿 細 } & \multicolumn{2}{|l|}{ 管 } & \multicolumn{2}{|l|}{ 間 } & 質 & \multicolumn{2}{|c|}{ 血 } & \multicolumn{2}{|r|}{ 管 } \\
\hline & & & & 胞 & & & 硒 & & I & 管腔拡 & & |场 & & & & & 大血 & & 中小血 & 血管 \\
\hline & & & & & & & & or & & 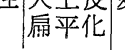 & & & & & & & 䇺型化 & 膨化 & 肥厚 & 壤死 \\
\hline 84 & - & - & & - & - & - & & - & - & -1 & - & - & - & - & - & - & - & - & - & - \\
\hline 89 & + & - & & - & - & - & & - & - & - & - & - & - & - & - & - & - & - & - & - \\
\hline 91 & - & - & & - & - & - & & - & - & - & - & - & - & - & - & - & - & - & - & - \\
\hline 96 & - & - & & - & - & - & & - & - & - & - & - & - & - & - & - & - & - & - & - \\
\hline 87 & - & - & & - & - & - & & - & - & - & - & - & - & - & - & - & - & - & - & - \\
\hline 90 & - & $=$ & & - & - & - & & - & - & - & - & - & - & - & - & - & - & - & - & - \\
\hline 93 & + & - & & - & - & - & & - & \pm & - & + & - & - & - & - & - & - & - & - & - \\
\hline
\end{tabular}

週間で可能である。

3. 組織学的变化

無処置腎には全く変化を認めなかつた。従つて以下に 記載するのはすべて狭窄腎に打ける変化である。但し JGA の変化については次項に記載するので,この項で腎 組織という場合には JGA を除いたものを意味する。一 般に組織学的変化は特に被膜下の部分に著明であつた。

1）短時間群

中等度狭窄では洼とんど変化を認めず，高度狭窄の No. 93のみ軽度の糸球体充血, 尿細管の混濁腫脹と部分 的な管腔の拡張を認めたが，血管系や間質には全然変化 が見られなかつた。

\section{2）軽度狭窄群}

糸球体の充血傾向は大半の例に見られたが機能的変化 と考光られる。糸球体の明らかな器質的変化は 1 力月群 のNo. 66に細胞増加を認めたのみであり，尿細管には13 例中 5 例に上皮細胞の扁平化，萎縮，混濁腫脹などが出 現したが壊死にまで至る例は見られなかつた，間質及び 血管系にはほとんど変化を認めなかつた。

3）中等度狭窄群

1 週間群では洼とんど器質的変化を認めない。2 週間 では糸球体に出血, 細胞増加, 萎縮, Bowman 囊細胞増 加などの器質的変化のいずれかが全例に出現するが，そ の程度は強くなく壊死は見られなかつた。尿細管は軽度

第 4 表 軽度狭窄群組織像

\begin{tabular}{|c|c|c|c|c|c|c|c|c|c|c|c|c|c|c|c|c|c|}
\hline \multirow{3}{*}{ 番号 } & \multicolumn{3}{|c|}{ 糸 } & \multicolumn{3}{|c|}{ 体 } & \multicolumn{2}{|r|}{ 尿 } & \multicolumn{2}{|c|}{ 細 } & \multicolumn{2}{|l|}{ 間 } & 質 & \multicolumn{2}{|c|}{ 血 } & \multicolumn{2}{|c|}{ 管 } \\
\hline & & & 細 & & & 囊細胞 & & 管腔拡 & & & & 盷 & & 大血 & & コ小血 & \\
\hline & 血 & 出 & 增 & 萎 & 壞 & 增 加 & 円 & 主 $\mid \begin{array}{l}\text { 大上皮 } \\
\text { 偏平化 }\end{array}$ & 変 & 噮 & 腫 & 浸 & & $\mid$\begin{tabular}{|} 
管壁 \\
膨化
\end{tabular} & 膨化 & 肥厚 & 壊死 \\
\hline 65 & - & - & - & - & - & - & $t$ & + & - & - & - & - & - & - & $1-$ & - & - \\
\hline 69 & - & - & - & - & - & - & - & - & - & - & - & - & - & - & - & - & - \\
\hline 74 & - & - & - & - & - & - & - & - & - & - & - & - & - & - & - & - & - \\
\hline 76 & + & - & - & - & - & - & \pm & + & + & - & - & - & - & - & - & - & - \\
\hline 56 & + & - & - & - & - & - & - & - & - & - & - & - & - & - & - & - & - \\
\hline 58 & + & - & - & - & - & - & - & - & - & - & - & - & - & - & - & - & - \\
\hline 75 & + & - & - & - & - & - & - & - & - & - & - & - & - & - & - & - & - \\
\hline 53 & - & - & - & \pm & - & - & $t$ & + & + & - & - & - & - & - & - & - & - \\
\hline 61 & + & - & - & - & - & - & \pm & \pm & + & - & \pm & + & \pm & \pm & - & - & - \\
\hline 64 & + & - & - & - & - & - & - & - & - & - & - & - & - & - & \pm & \pm & - \\
\hline 66 & + & - & + & - & - & - & \pm & - & \pm & - & - & - & - & - & - & - & - \\
\hline 72 & + & - & - & - & - & - & - & - & - & - & - & - & - & \pm & - & - & - \\
\hline 78 & + & - & - & - & - & - & - & - & - & - & - & - & - & - & - & - & - \\
\hline
\end{tabular}


第 5 表 中等度狭窄群組織像

\begin{tabular}{|c|c|c|c|c|c|c|c|c|c|c|c|c|c|c|c|c|c|c|c|}
\hline \multirow{3}{*}{ 番号 } & \multicolumn{3}{|c|}{ 系 } & \multicolumn{2}{|l|}{ 球 } & \multicolumn{2}{|c|}{ 体 } & \multicolumn{2}{|c|}{ 尿 } & 細 & \multicolumn{2}{|l|}{ 管 } & \multicolumn{2}{|r|}{ 間 } & 質 & \multicolumn{2}{|c|}{ 血 } & \multicolumn{2}{|c|}{ 管 } \\
\hline & & & & 胞 & & & 霊細胞 & & & & 性埴 & & & & 胞 & 大血 & & 小血 & \\
\hline & & & & & & & & & 偏平花 & & & & & & & 膨売 & 膨化 & 肥厚 & 壞死 \\
\hline 54 & - & - & - & - & - & - & - & - & - & - & & - & - & \pm & - & - & - & - & - \\
\hline 55 & - & - & - & - & - & - & - & - & - & - & & - & - & - & - & - & - & - & - \\
\hline 67 & - & - & - & - & - & - & - & - & - & \pm & & - & - & - & - & - & - & - & - \\
\hline 88 & \pm & - & - & - & - & - & - & - & - & - & & - & - & - & - & - & - & - & - \\
\hline 82 & - & - & - & - & \pm & - & - & + & - & + & & - & - & - & - & - & \pm & + & - \\
\hline 83 & \pm & - & \pm & 上 & - & - & - & \pm & \pm & \pm & & - & - & - & - & - & - & - & - \\
\hline 85 & $t$ & $t$ & + & $t$ & - & - & + & - & + & + & & - & - & - & $=$ & - & - & - & - \\
\hline 86 & $\overline{-}$ & - & $=$ & 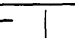 & \pm & - & $=$ & - & $=$ & + & & $=$ & - & - & - & - & \pm & \pm & $=$ \\
\hline 92 & \pm & \pm & \pm & \pm & - & - & - & \pm & \pm & \pm & & - & \pm & - & - & - & - & - & - \\
\hline 63 & - & + & \pm & & \pm & - & - & \pm & $t$ & + & & - & \pm & \pm & - & - & - & - & - \\
\hline 68 & $t$ & \pm & + & 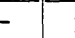 & \pm & - & - & + & + & + & & - & \pm & + & \pm & - & + & \pm & - \\
\hline 80 & - & - & - & - & - & - & - & \pm & \pm & + & & - & \pm & + & + & - & \pm & - & - \\
\hline 94 & - & - & - & - & - & - & - & \pm & - & + & & - & - & - & - & - & \pm & - & - \\
\hline 95 & - & \pm & \pm & $E$ & - & - & \pm & - & - & \pm & & - & - & $=$ & - & - & - & - & - \\
\hline
\end{tabular}

第 6 表 高度狭窄群組織像

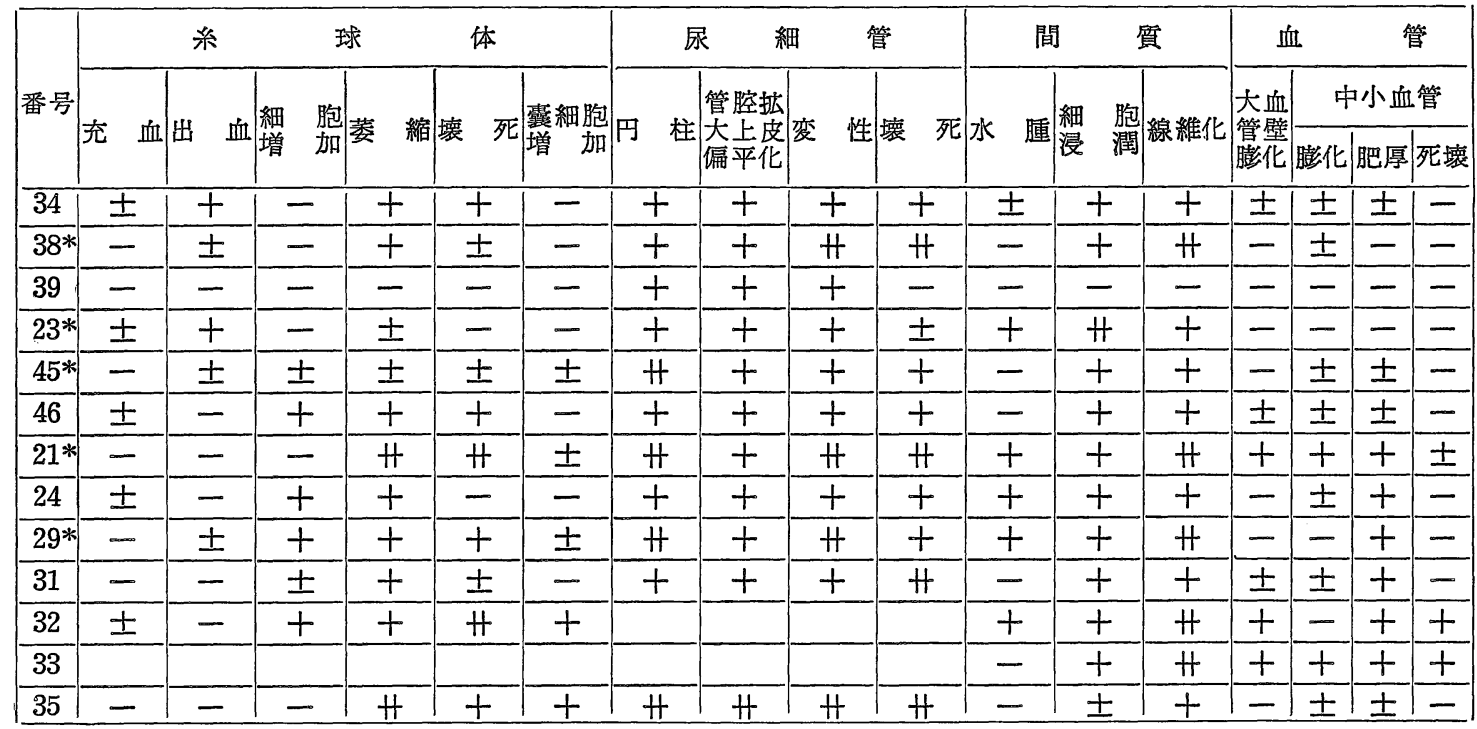

*印を付した例は変化の強い部分以外にほぼ正常に近い部分もみられるるのを示す.

狭窄群に比べ上皮細胞の変性はかなり強いが，壤死に陥 つた例はない，間質にはほとんど変化なく，2 例に小葉 間動脈の軽微な壁の膨化ないし肥厚を認めたの

1 カ月群も系球体，尿細管には 2 週間群とほぼ同様の 組織学的所見を呈したが，間質殊に血管周囲の部分に浮
畽, 細胞漫潤, 線維化などの出現を見た。

\section{4) 高度狭窄群}

1 週間で既に器質的変化の出現を見た。すなおち糸球 体には 3 例中 2 例に血管腔拡張, 出血, 萎縮, 壊死が見 られ，尿細管も变性のみならず，部分的な強い壊死を来 
写真1 正常腎傋造 (No. 20) H-E 染色 $\times 40$

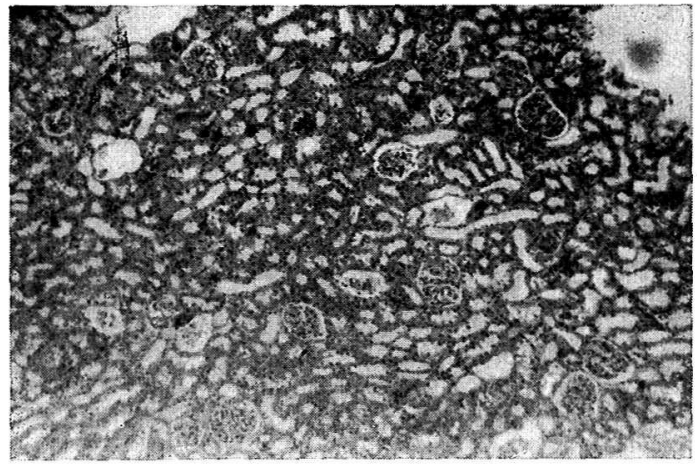

写真 3 被膜下部の強い壊死 (No. 46) H-E 染色 $\times 40$

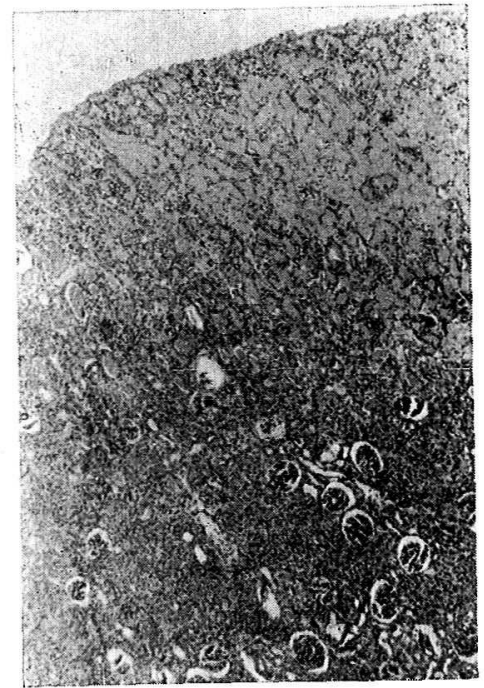

写真 5 尿細管の混濁腫脹 (No. 53) H-E 染色 $\times$ 400

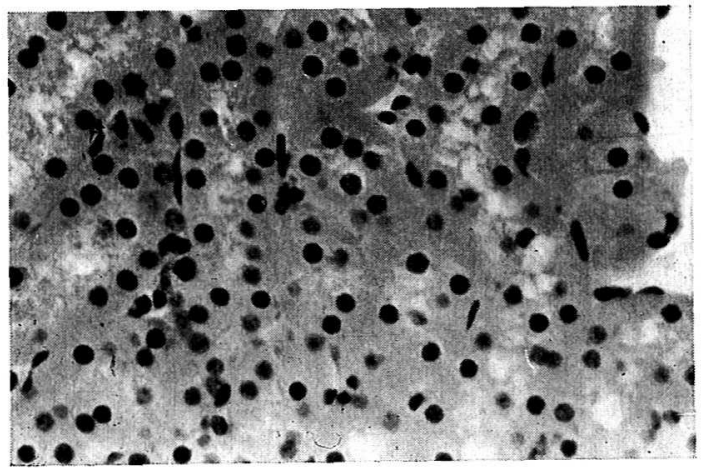

写真 2 系球体萎縮, 尿細管变性, 壊死, 間質細胞 浸潤，線維化（No. 24）H-E 染色 $\times 40$

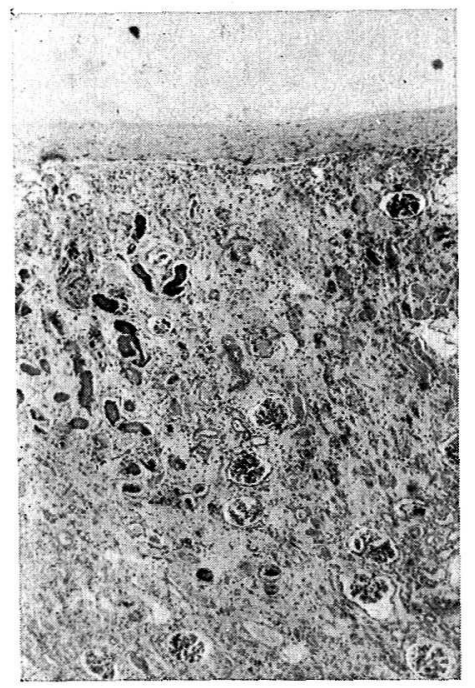

写真4 腎構造注とんど 消失 (No. 33) H-E 染色 $\times 40$

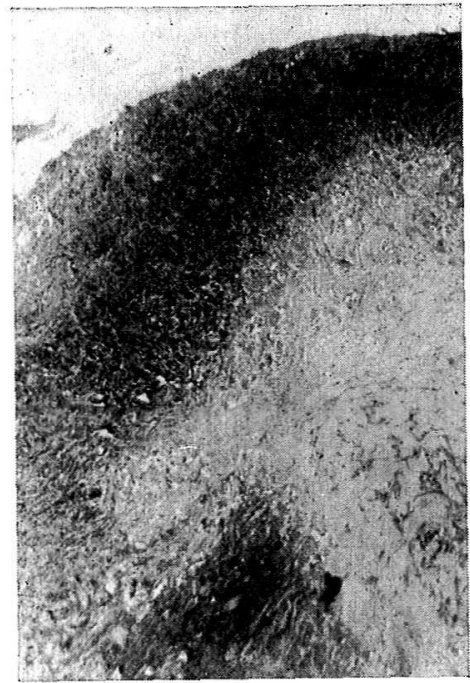


写真 6 糸球体の出血 (No. 68) H-E 染色 $\times 100$

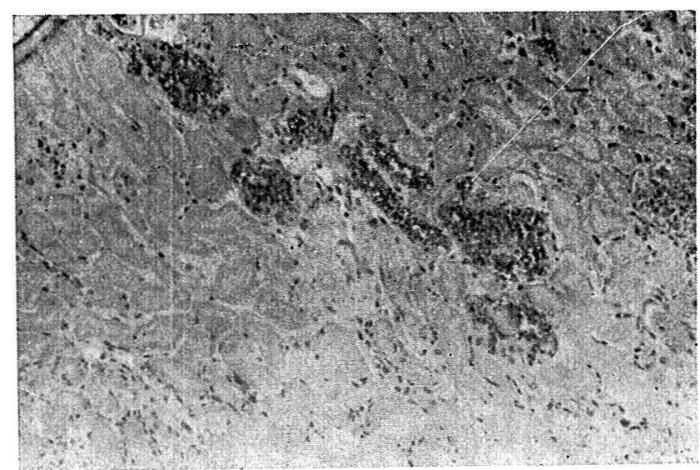

写真 8 間質性細胞浸潤 (No. 68) P A S 染色 $\times 200$

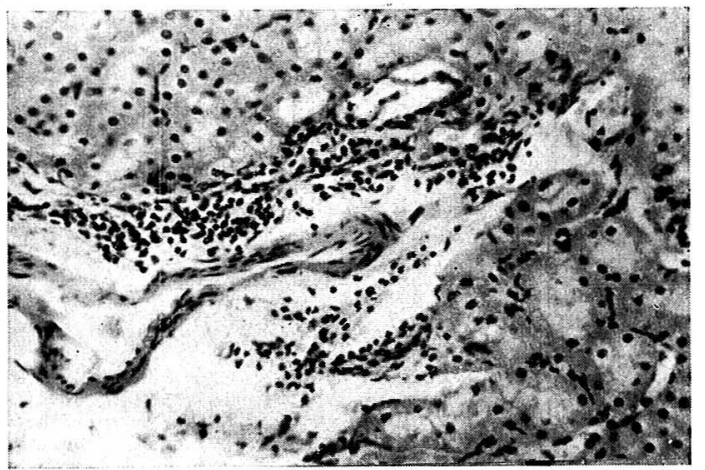

写真10 小葉間動脈内膜膨化, 外中膜肥厚 (No. 45) $\mathrm{M}-\mathrm{T}$ 染色 $\times 600$

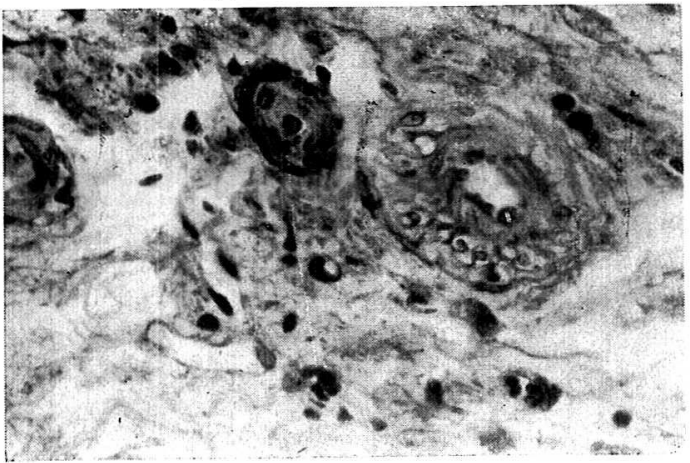

写真 7 糸球体細胞増加 (No. 66) H-E 染色 $\times 400$

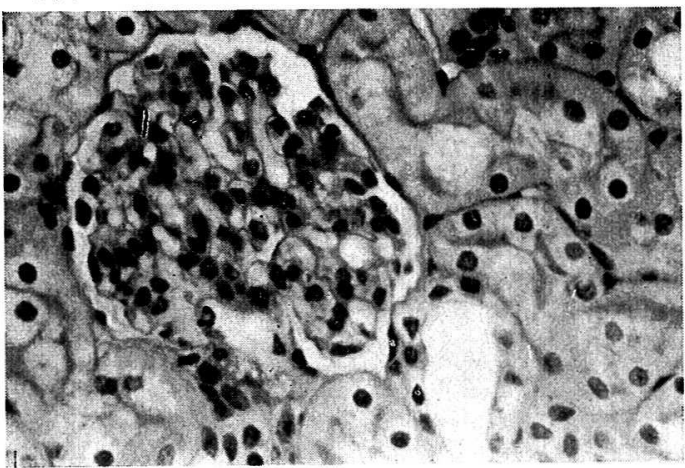

写真 9 Bowman 囊細胞增加（No. 85） P A S 染 色 $\times 400$

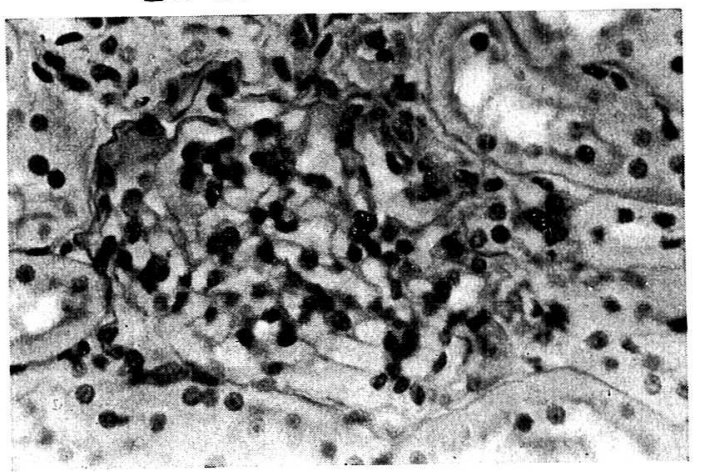

写真11]J G I の I 度 (No. 74狭窄側) Bowie 染 色 $\times 600$

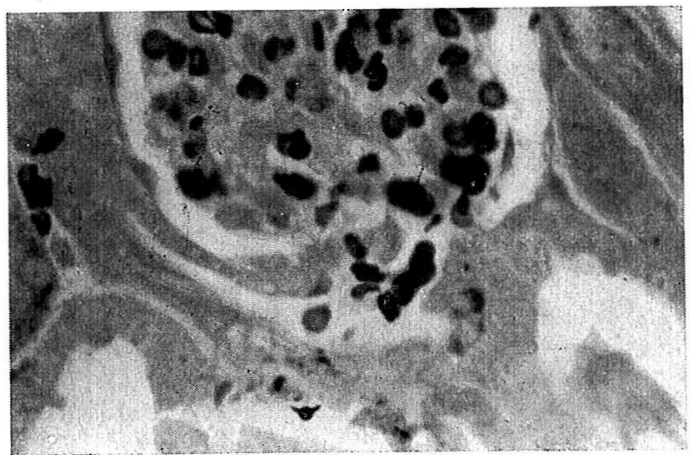


写真12 J G I の I 度（No. 34無処置側）Bowie 染 色 $\times 600$

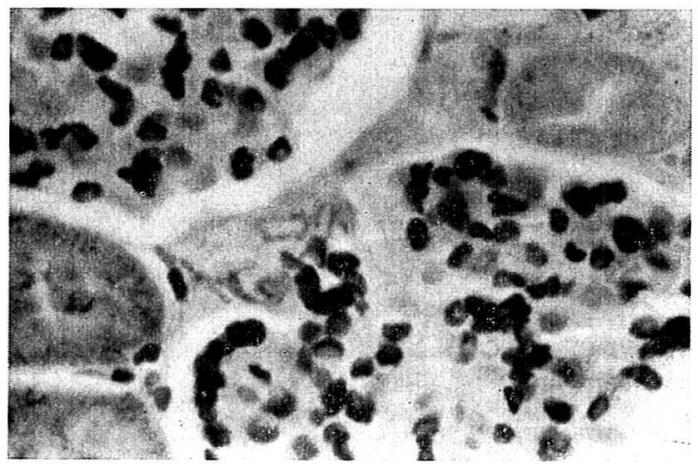

写真14 J G I の III度（No. 75狭窄側）Bowie 染色 $\times 600$

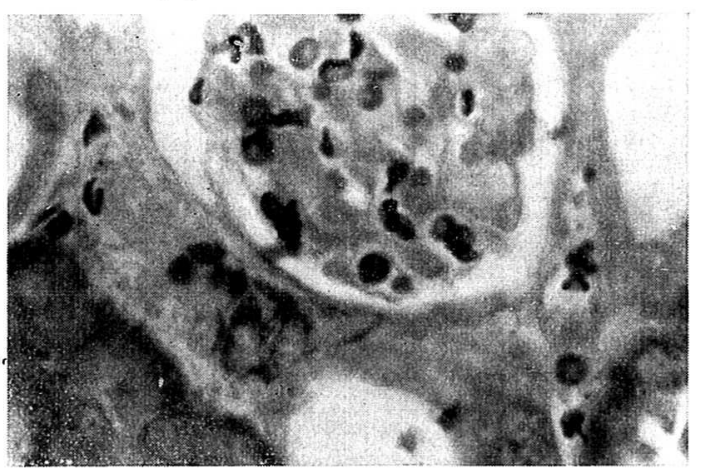

写真16 J G 細胞增生, J G I 0 度（No.76狭窄側） Bowie 染色 $\times 600$

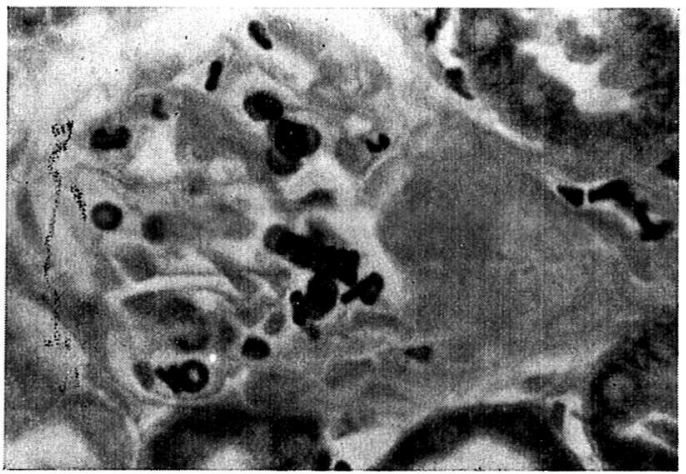

写真13 J G I の II 度 (No. 67狭窄側) Bowie 染 色 $\times 600$

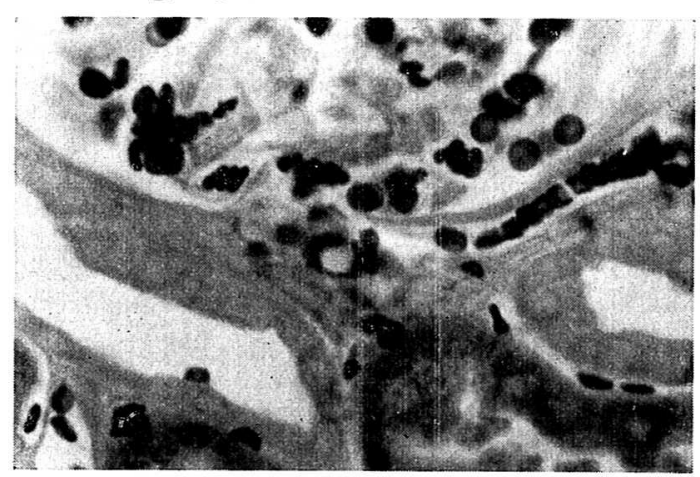

写真15 J G I の III 度 (No. 55狭窄側) Bowie 染色

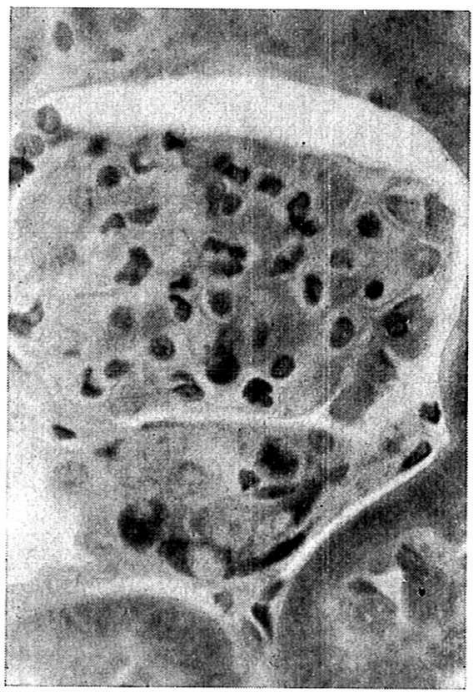

写真17 J GAのみあり所属する系球体不明 (No. 27 狭窄側) Bowie 染色 $\times 600$

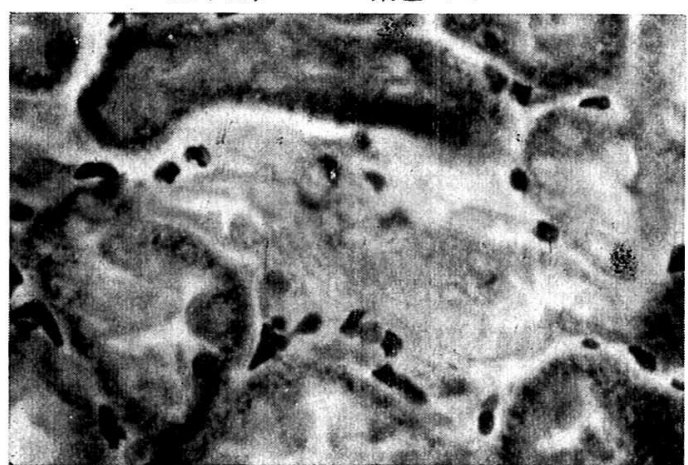


写真18 軽度狭窄の腎動脈像（No. 75）

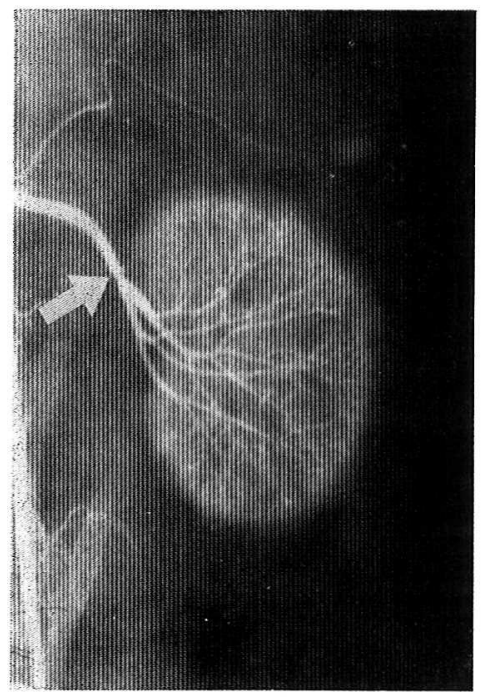

写真19 中等度狭窄の腎動脈像（No. 86）

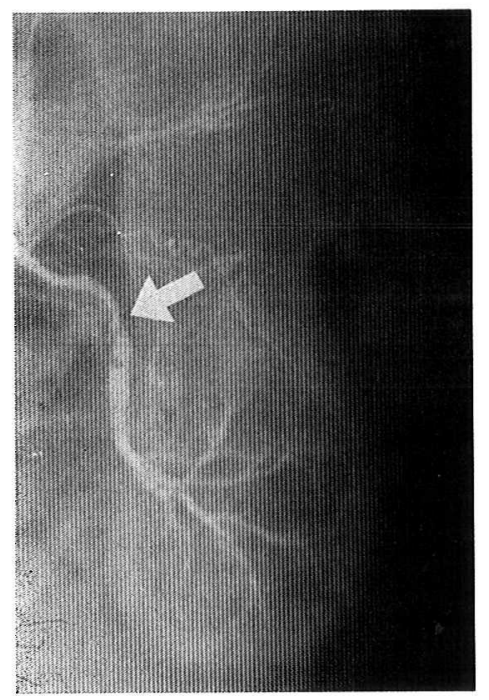

たし，間質にも線維化，細胞浸潤を主体とする強い変化 を生じた。

中小血管にも内, 中膜の肥厚，外膜の膨化を認める例 があつた。

2 週間群は 1 週間群に比べ系球体, 尿細管, 間質, 中 小血管のいずれにも強い組織学的所見を呈した。

1 カ月群では 2 例が腎全体が梗塞状態となつたが, 栄 状に正常組織が残存し, 全例に中小血管壁の肥厚を見 た.
写真20 高度狭窄の腎動脈像（No. 46）

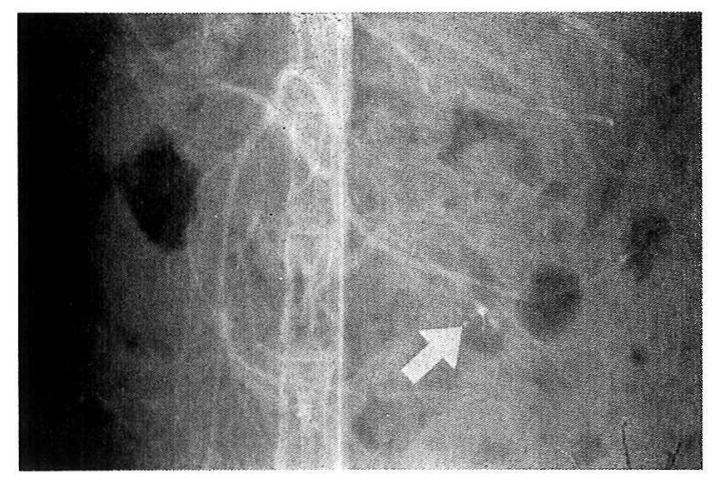

3 カ月群は腎全体が著明に萎縮し, 变化が高度な例で は腎構造が注とんど消失し, 壊死組織と線維性結合織の みを示した。

腎動脈狭窄による組織学的変化は腎全体に一様に起こ るのではなく, 初めは正常腎組織の中に巣状に変性や壊 死が出現し, 後になると壊死組織の所所に巣状に正常に 近い組織が残存していた.

4. JGA の変化

前述のごとく JGA の機能を組織学的に表現する index 枆々の方法があるが, 著者は JGI と IJGA で その変化を追求した。な和前述のごとく正常の JGI は 15〜30, IJGA は20〜30とし, それ以上の場合は増加, 以下の場合は減少と見なした。

1）短時間群

第2 表で見られるごとく，24時間では JGI は狭窄腎 でも無処置腎でも減少したが，その平均は狭窄腎13.0, 無処置腎 3.0で無処置腎の方が著減を示した. IJGA は やや狭窄側の方が高いがその差は大さくない，

3 日では JGI は No. 90のみ両側とも減少している が, 他の 2 例の狭窄側は正常化している. IJGA は血圧 上昇した No. 93に左右差がらかが党る。

2) 軽度狭窄群

まず 1 週間では, 高血圧となつた 2 例は狭窄側の JGI は增加しているが，血圧の上昇しない2 例はか党つて 無処置側の JGI の方が高值を示した. IJGA は高血圧 では無処置側は正常であるが, 狭窄側での増加が強いた めに両側間の差が大きくなつている.

一方血圧の上昇しない 2 例はその差が小さいか, 逆に 無処置側の方が高值を示している．2 週間群に抏いても JGI と IJGA は 1 週間とほぼ同様の成績が得られた。 
No.75の狭窄側 IGI 86，IJGA 46といら值は，全症例 中最高であり, この例は血圧上昇度も最高であつた。

1 カ月では高血圧 2 例のらち 1 例はやはり狭窄側の IGI と IJGA は增加しているが， 1 例の JGI は正常 である。

\section{3）中等度狭窄群}

1 週間群のら号高血圧 2 例と非高血圧 2 例は明確な相 違を示した. 高血圧例では 2 例とも狭窄側の JGI は著 増し, 同時に IJGA も増加して無処置側と大きな差を 生じた。

これに対し非高血圧例では無処置側の JGI は軽度に 減少あるいは増加し，狭窄側との差が小で，IJGA の 差も小さい。

2 週間では高血圧例 3 例のらち 2 例は JGI は無処置 側 0 , 狭窄側著增といら定型的所見を示し, IJGA は 3 例 とも狭窄側で増加していた。

1 カ月群でもほぼ同様の成績を示した。

4) 高度狭窄群

高度狭窄では軽度あるいは中等度狭窄群とは全く異な る成績が得られた。この群では全例を通じ 2 週間以後で は狭窄側の JGA に全く顆粒を認めなかつたが，これは 後で述べるようにこの群の組織学的変化が特に 2 週以後 に著明であることと関係があるのではないかと思われ る。

まず 1 週間群では高血圧例 2 例の JGI は無処置側の 方が増加していた。非高血圧例は両側とも正常で明らか な差は見られなかつた。

2 週間では無処置側の JGI はまちまちであり, IJGA は非高血圧例の 2 例で狭窄側の減少が明らかであつた。

1 カ月では無処置側の JGI は正常あるいは軽度の増 加を示し，IJGA は無処置側でほぼ正常。狭寉側では やはり減少していた。 3 カ月では No。32及び33のごと く, 狭窄側の IJGA が0 といら例すら見られた。

\section{V。総括並びに考按}

1. 血圧の変化

先人の報告によると，確実に持続的高血圧を作成する には，一側腎摘除十他側腎動脈狭窄を行ならか，両腎動 脈狭窄を行なら方がよく，一側腎動脈狭窄だけでは血圧 は上昇してる軽度で一時的であるとされている。

著者は短期間群の 7 例を除いて40例中17例に高血圧発 生を見たが，その中5例は 1 カ月群である. Bounous and Schumacker ${ }^{138)}$ (1962) も一側腎動脈のみの狭窄で 犬90頭中65頭に中等度の持続的高血圧が得られたと述べ
ており，両腎動脈狭窄や単腎の腎動脈狭窄が一側腎動脈 狭窄に比較し臨床で経験する頻度が少ないことも考慮に 入れると，高度の高血圧は得られぬが，組織学的研究を 目的とした研究で採用するのに好ましい方法であると思 われる。

高血圧の発生は全例が 5 日以内であり，一般に考学ら れているよりも早く血圧上昇が始まることは明らかであ る. 高血圧の発生は狭窄の程度によつて異なり, 中等度 群の約 $64 \%$, 軽度群の約 $38 \%$ ，高度群の 約 $24 \%$ 飞発生 し，中等度狭窄の場合に最も高血圧が発生しやすいとい う結果を得たが，血圧の上昇幅には各群で著明な差異は 見られなかつた。

高度狭窄 ${ }^{130)}$ や軽度狭窄 ${ }^{139)}$ で血圧上昇が著明とする説 もあるが, Bounous and Schumacker は腎動脈の狭窄 の程度により完全に閉塞したものを第 1 群，以後最小の 狭窄までを 6 群に分けると。血圧の平均はとれぞれ 145， $159 ， 167 ， 170 ， 158 ， 136$ となり, 中等度狭窄群の 血圧上昇が最も著明であつたと報告しまた龟山 ${ }^{1211}$ は Goldblatt 変法による実験的家鬼脳出血の研究で, 最も高率に脳実質大出血を起こしうる腎動脈狭窄度は中 等度であることを知つたと述べている。著者の得た，中 等度狭窄の場合に高血圧を生ずる割合が最も高いという 結果に加えて，著者の実験では見られなかつたが，中等 度狭窄で最も著明な血圧増加を得る ${ }^{132) 138)}$ というこれら の報告から，腎動脈の狭窄の程度が高血圧の産生に決定 的な役割を演ずることが明らかであり，高血圧が血流障 害すなわち腎虚血の程度と単に比例しないことが判明 し, 高血圧発生機序の一端をらかがわせ興味深い。

2. 組織学的変化について

JGA の変化は後述するので，ここでいら腎組織には JGA を含まず，従つて中小血管という場合にも旁系球 体部の糸球体輸入血管は含まれていない。

腎動脈狭窄処置後の腎組織の変化についての報告はか なりあるが，如何程の狭窄により腎の各組織に如何程の 日時で変化が起こるかを系統的に観察しそそれと血圧と

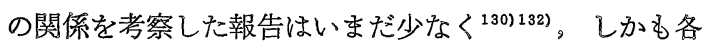
人によつてその成績が非常に異なる。例を Bowman 囊 の変化にとつてみると突戸，夏目 ${ }^{133)}$ は処置後 2 週間で Bowman 囊の浮腫を認めているのに対し,Goldman ${ }^{127)}$ は6〜12カ月でようやく変化を見出している。この原 因としては次の 2 つ因子が考光られる。1つは一側の みの処置かあるいは他側にも何らかの処置を加えたかが 問題であり，両側を処置した場合には当然変化の出現が 
早くかつ強くなる，他の 1 つは狭窄の程度であり, 狭窄 が強いと組織障害も著明であろうことは容易に推測でき る。

著者は前述のごとく全例を一側腎動脈狭窄術に統一し たうえ，狭窄程度を 3 段階に分けて各組織变化を経時的 に観察することができた。 その結果は第 3 〜表に示す ごとくで狭窄の程度の弱いものと強いもので非常に大き な差異があらわれた。

すなわち処置後24時間では組織学的変化は認めず， 3 日でも高度狭窄側にわずかに糸球体の充血, 尿細管上皮 細胞の混濁腫脹を認めるのみであるが，1 週間では軽度 狭窄群及び中等度狭窄群のいずれにも活とんど変化は見 られないのに比し, 高度狭窄群では1 週間で既にかなり 強い組織学的変化を示し, 処置後 2 週間では軽度狭窄群 については尿細管に軽度の変化を見る例があるがほとん ぞの例に変化なく, 中等度狭窄群では系球体に出血, 萎 縮, 細胞増加などの器質的変化を見る例が出現するが, 間質や血管には活とんど変化を生じないのに比し, 高度 狭窄群では変化が一層高度になつた. 処置後 1 カ月では どの狭窄群でる，2週間で見られた組織学的変化を一層 著明にした所見が得られた。

以上の著者の成績から判明したことは，まず狭窄の程 度如何が組織学的変化の出現する速さ及び変化の程度に 想像以上の差異を生じさせることである。すなわち腎の 各組織が一様に变化するのではなく，尿細管に最も早く 変化が出現し，次いで系球体にも変化が現われるが，間 質と中小血管の変化はかなり遅れ，各組織間に大きな相に 違が見られることが明膫となつた。

著者の成績を，同様に腎動脈狭窄後各週毎に腎組織の 変化を観察した穴戸・夏目 ${ }^{133)}$ の報告と比べると，変化 の出現速度はかなり遅れているが，他側腎を摘除したか 否かによる差異と思われる。動脈狭窄実験ではないが一 時的腎動脈阻血実験を行なつた石沢 ${ }^{140)}$ (1960), 池上 ${ }^{132)}$

(1961)，太田 ${ }^{141)}$ (1964）らの成績をみても，組織学的 変化は尿細管が主で糸球体，Bowman 囊，間質などに は変化が少ない。

腎組織とりわり血管系の組織学的変化と血圧とに何ら かの関係を見出すことを期待したが，明確な関係は得ら れなかつた。すなわら中小血管壁の膨化，肥厚，壊死な ぞの変化は軽度狭窄群の 1 例, 中等度狭窄群の 5 例及び 高度狭窄群の11例, 合計17例隹認めているが, そのうち 高血圧例はわずかに中等度及び高度狭窄群に各 2 例見ら れるにすぎず，残りの15例には全く中小血管の変化を認
めていない，糸球体，尿細管，間質などについても血圧 との関係は証明されなかつた。西森 ${ }^{135)}$ は腎小動脈の中 膜変性を主とする血管病変が高血圧の発生に病因的な意 義があると主張しているが著者は後述する JGA の変化 を除いては第 $2,4,5,6$ 表から明らかなごとく, 系球体, 尿細管，間質などと同様に狭窄の程度と深い関連を有す るが，血圧の上昇如何とは無関係に近く，高血圧の成因 としては考えられないとの結論を得た。

3. JGA の変化について

著者の実験は一側腎動脈のみの処置で他側腎には処置 を加えず，乙かも生検による腎組織への影響を避けるた めに，術後一定期間で各群に分けて屠殺しているので， 無処置腎の JGA の変化も重視されている ${ }^{105)}$ 現在, 両 腎の変化を比較するのに好都合である.

著者は 1）JGA の変化が狭窄の程度によつて如何 に相違するか，2） JGA の变化が時間的に如何に推移 するか，を組織学的に究明し高血圧発生に関与すると思 われる JGA の変化をいくらかでも明らかにし，その意 義について考察すると同時に，3） JGA の新しいindex として著者の考案した IJGA が用いるに足る index で あることを立証せんとした。

1）狭窄の程度による影響

前述のごとく腎動脈狭窄術後の JGA の変化について 記載した文献は多数あるが，狭窄の程度によつて如何な る相違が生ずるかを観察した報告は見当らない，著者は JGA が血圧のみならず狭窄の程度, ひいては組織障害 の程度とも何らかの関連を有するのではないかと考光た が，その結果は前記のごとくである.

すなわち JGI で比較すると, 軽度狭窄群では両側 とも正常範囲内にあるもの 1 例, 両側とも減少せるもの 1 例, 無処置側は減少するが狭窄側が増加せるるの 3 例, 無処置側は減少し狭窄側正常のもの 6 例, 無処置側 正常で狭窄側が増加せるもの1例であつた。

中等度狭窄群では両側とも正常のもの 1 例, 無処置側 で減少するが狭窄側は正常のもの 6 例, 無処置側で減少 乙狭窄側で増加せるもの 6 例, 両側とも増加しているも の 2 例であり, 高度狭窄群では両側とも正常のもの 1 例, 両側とも減少せるもの 2 例, 無処置側で増加するが 狭窄側正常のもの 2 例, 無処置側正常狭窄側減少 4 例, 無処置側で増加し狭窄側減少せるもの 4 例であつた.

以上の成績より狭窄の程度によつて JGI の変化が異 なることが明らかであり，両側の JGI の変化を比較図 示した第 $1,2,3$ 図に見られるごとく，軽度狭窄群と中等 
第 1 図 軽度狭窄群両側腎の J G I の比較

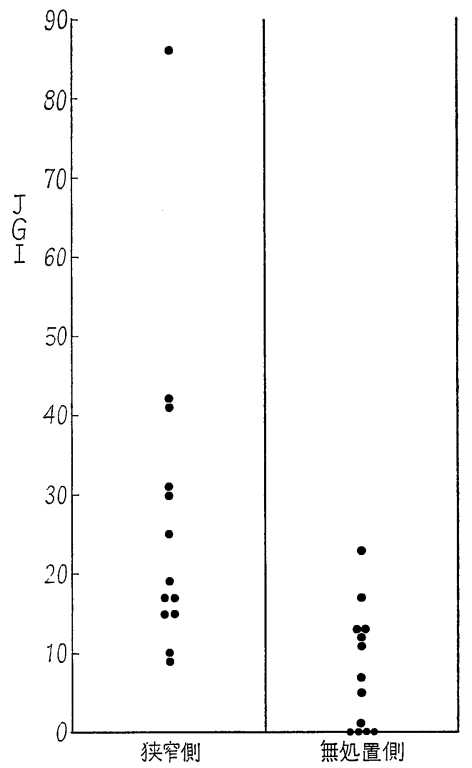

第 2 図中等度狭窄群両側腎 J G I の比較

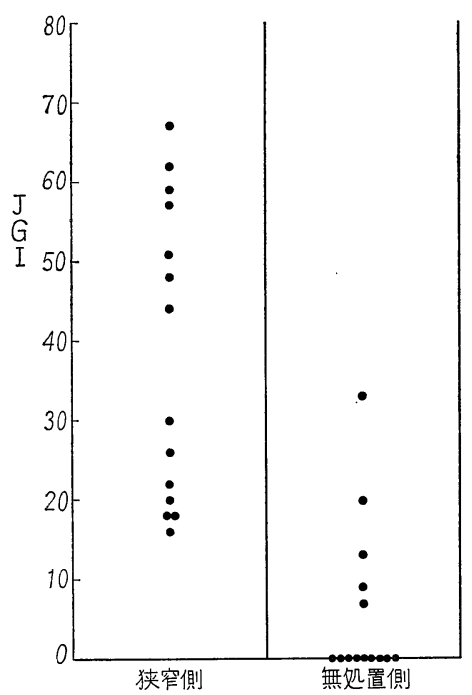

度狭窄群との相違はまだしも, 高度狭窄群に至つては他 の 2 群と全く正反対と言つてもよい程の変化を示してい る.すなわら軽度狭窄群と中等度狭窄群はほぼ類似して いるが，第 1,2 図を比較すると中等度群の方が両側間の 差が大となつている。しかし高度狭窄群では軽度及び中 等度狭窄群とは逆に，狭窄側の減少が著明で13例中10例 までも JGI は0であつた。
第 3 図高度狭窄群両側腎 J G I の比較

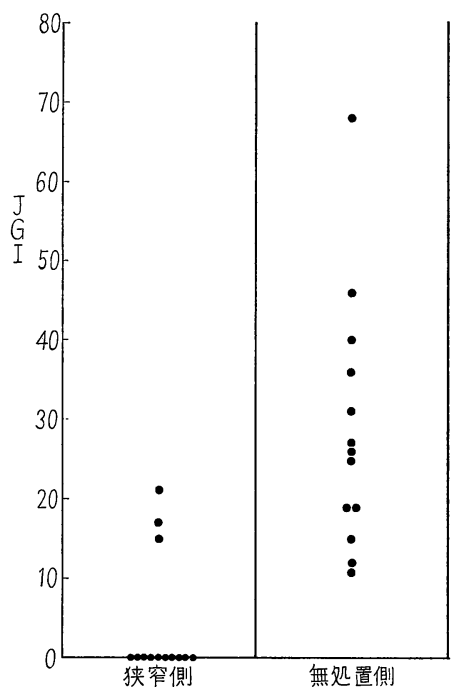

従つて予想したと招り, JG 細胞は狭窄の程度如何に よつても非常な影響をらけることが判明したが，特に興 味深いのは第 1 亿腎の系球体, 尿細管, 血管などの組織: が前述のごとくほぼ狭窄の程度に比例した影響をこうむ つているのに対し，JG 細胞は狭窄に比例した変化を示 さないことと，第 2 亿狭窄が強いために狭窄側 の JGI が 0 となつてしまつた13例のうち，1例の例外を除いて 高血圧例が見られぬことである.

以上より JG 細胞は狭窄に対する抵抗性は比較的強: く，その機能を維持するが，あまり狭窄が強くなると JG 細胞自体も虚血による障害をこうむり，JG 細胞と しての機能を営みえず, 従つて JGI などの index も適 用できないことが明らかとなつた。

また中等度狭窄が最も高血圧を生じやすく，高度狭窄 では最も生じにくく，JG 細胞は中等度の狭窄までは機 能を維持するが，高度になるとその機能が障害されると いう著者の実験成績を総合すると，高血圧発生機序に JG 細胞が如何に深い関連を有しているかが明白であ り，軽度狭窄より中等度狭窄の方が高血圧となりやすい のは，JG 細胞がその機能を果たしている為であり，高 度狭窄の場合に高血圧を生じにくいのは JG 細胞がその 機能を失つたためであるとして理解できる。

2） JGA の変化の時間的推移

文献的にみて renin がJG 細胞顆粒に含まれているの は注ぼ確実であることは前述したが，JG 細胞がはたし て内分泌腺として期待される反応に適合した変化を示す 
かどらかについて経時的に 詳しく観察 した報告は少な い.わずかに Miller and Hartrof $\mathrm{t}^{142)}$ (1961) はラッ トに $\mathrm{Na}$ 欠乏食を与兄ると数時間で JG 細胞顆粒が減少 し，その後も $\mathrm{Na}$ 欠乏食を与え続けると顆粒が次第に増 加することを発見，刺激による顆粒の初期放出とそれに 続く顆粒の加速度的生産といら内分泌腺特有の变化に一 致するとし, Hirashima and Takaku ${ }^{143)}$ (1962) はラ ツトに出血を起こすと JGI は出血後約20時間で急激に 増加しはじめ, 4 日後に最大に達し, 以後急激に減少し たとし，顆粒化度は erythropoietin の生産と並行する と述べている.

著者は腎動脈狭窄の場合でもやはり内分泌腺に適合し た变化を JG 細胞が示すことを期待し，また同時に JGI が狭窄後如何程の日時で分泌の指標となりらるかにつ いても本実験で明らかにしたいと考光，前記の所見を得 た。

すなわち狭窄後24時間では顆粒は狭窄側, 無処置側の いずれでも減少するが無処置側の減少の方が著明で， 3 日になると無処置側の減少は続くが，狭窄側では正常に 戻つた. 1 週間以後は軽, 中等度狭窄と高度狭窄では異 なり, 前者の場合には狭窄側の顆粒は 1 週間で正常以上 飞増加している例が多く，2 週間及び 1 カ月後でも同様 の傾向が続いた．高度狭窄の場合，1週間以後では無処 置側の方が狭窄側より顆粒が多く，2 週間以後では狭窄 側の顆粒は全く消失した。

以上の所見より腎動脈狭窄の場合でも, 少なくとも狭 窄が高度のため JG 細胞自体も障害される場合以外は, 狭窄側の JG 細胞は狭窄後数日間の顆粒減少, 1 週間以 後に怙ける増加という反応を示すことが明らかで, 後述 する IJGA の変化とも合わせ, 内分泌腺としての反応 飞適合した所見が得られた. また JG 細胞顆粒の初期放 出と見なされる期間はかように処置後数日間にすぎない ので，少なくとも 1 週間以後では顆粒の増加すなわち JGI の増加は分泌の増加を表わすとしてさしつかえない と考学れる。

3) IJGA について

組織学的に JG 細胞の機能を半定量的に表わそうとし て種々の方法が試みられていることは前述したが ${ }^{107) ~ ~}$ 117)，そのいずれにも一長一短がある. JGI は顆粒の増 滅を表わすのには非常に優れた方法であり，JGI の考 案により JGA の研究が飛躍的に発展した活どである が, 残念ながら顆粒の増減以外の変化を表現できない。 一方 JGCC は細胞数の増減を表わし偏腎性高血圧の手
術適応決定に役立つとされているが，対象とする糸球体 が25個でははたしてその腎全体の変化を表わしらるかど らか疑問であり，また細胞の増生を表現できても肥大は

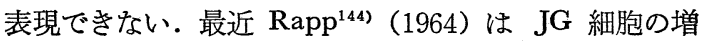
生と共に肥大の指標として Index of hyperplasia and Hypertrophy なる index を考案したが，副腎再生高血 圧ラットでは有意義な変化を認めなかつたと述べてい る. Rapp の方法は標本の全視野に数えうる JGA の数 を全糸球体数位対する百分率で示すものであるが，標本 の全視野の JGA 数を数えるのはラットのような小動物 の腎標本の場合はまだしも，他の動物では実際には非常 に困難である，以上の現状にかんがみ，著者は前述の IJGA なる単位を考案したが，IJGA は1） Bowie 染色 により同時に顆粒の如何も観察できる，2）増生と同時 に肥大の index となりらる，3）対象とする系球体が 100個であり，対象が多すぎるために起こる実際的な困 難性もなく, 対象が少ないために起こる誤りも少ない, 以上 3 つの利点から優れた index となるのではないか と期待した。

その結果は予期したと和り，1） IJGA は JG 細胞の 増生や肥大に対する有意義な index となり，2） JGI と対比すると JG 細胞の変化が一層明確に理解でさるこ とが明らかになると同時に，3）最も優れた点として， JGI と同等あるいはそれ 以上に血圧との関連が深いこ とが判明した。

すなわち IJGA は処置後数日間は变化しないが，軽 -中等度狭窄では 1 週間以後, 血圧上昇例の及狭窄側 の IJGA が増加する，狭窄が高度の場合には狭窄側の IJGA は 1 週間以後次第に減少するが無処置側は变化 しない.JGI 及び血圧の変化と照合すると，狭窄後 24 時間以内に JG 細胞の顆粒が狭窄側でも無処置側でも放 出され, その結果数日以内に血圧上昇が起こり, 無処置 側ではもはや顆粒産生は行なわれないが，狭窄側では 1 週間後までに顆粒の産生, そして叔そらく放出も増加す ると同時に, JG 細胞の増生や肥大が起こるといら一連 の経過を辿ることが高度狭窄以外の血圧上昇例について 明らかである。

血圧との関連については第 4 図に見られるごとく，高 血圧時には狭窄側の IJGA が著増するために非狭窄側 との開きが大きくなるが，非高血圧群ではかかる変化は 見られない. 狭窄側の IJGA と血圧上昇幅との関係を 図示した第 5 図でも血圧上昇との平行関係がうかがえる が，狭窄側と非狭窄側との IJGA の差を一方の軸にあ 
第 4 図 軽及び中等度狭窄群の両側腎 I J G A

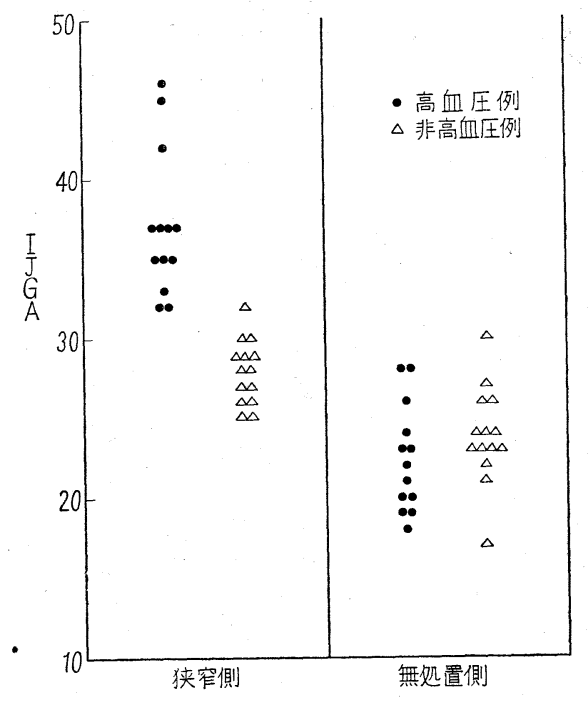

第 5 図 軽及び中等度狭窄群の狭窄腎 I J G A と血 圧との関係

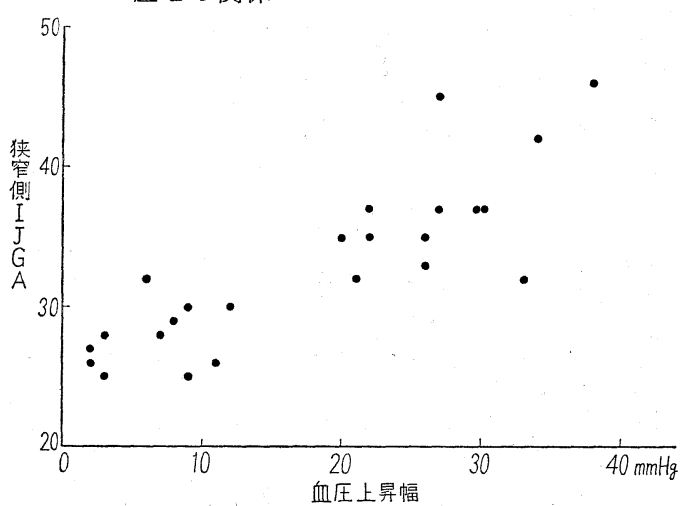

但しN $0.58,64,82$ は除く

第 6 図 軽及び中等度狭窄群両側腎 I J G A と血圧 その関係

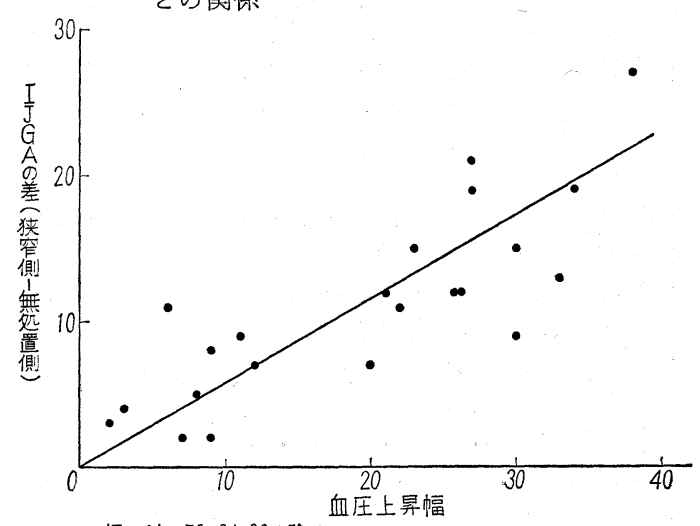

但し N $0.58,64,82$ を除く
第 7 図 軽及び中等度狭窄群狭窄腎 J G I と血圧 と の関係

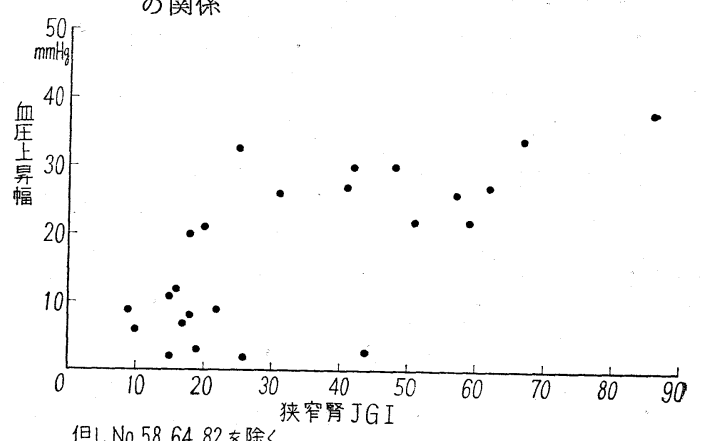

但 L N $0.58,64,82$ を除く

第 8 図 軽及び中等度狭窄群両側腎 J G I

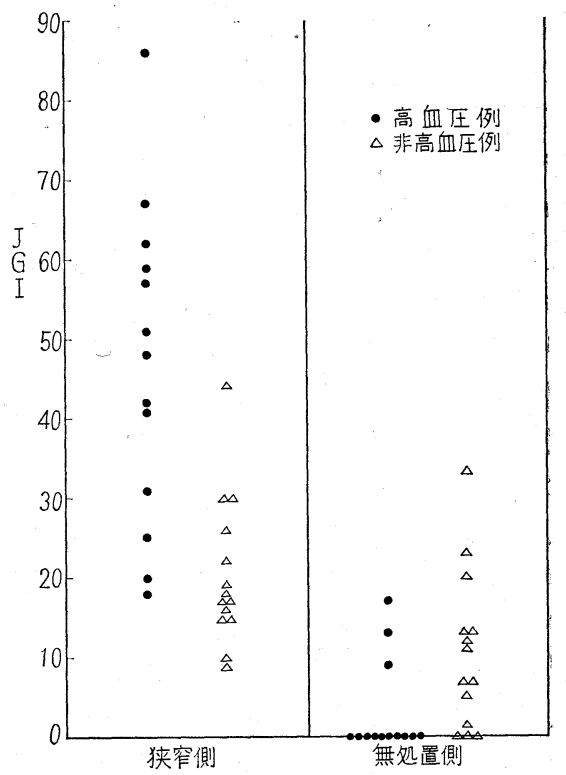

第 9 図高度狭窄群両側腎 J G I

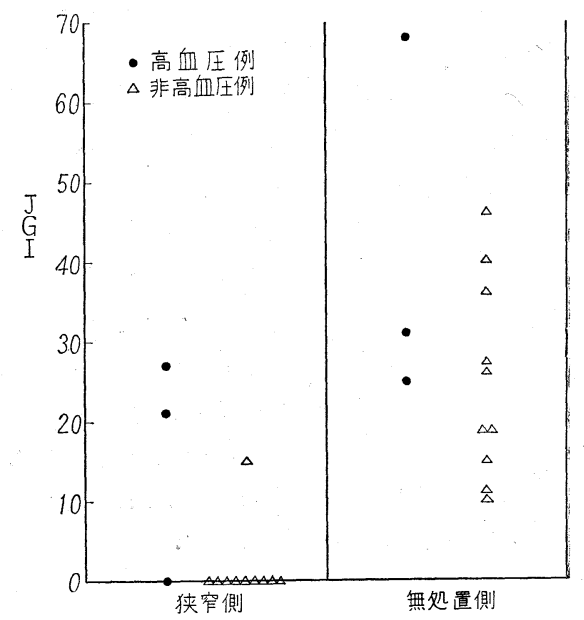


らわしても，第 6 図に見るごとく血圧上昇との間に非常 に有意義な比例関係が成立した. 難点は JGI と同様, 高度狭窄の場合には指標となり光ない点であるが，少な くとも狭窄側の IJGA が30以上で，無処置側との羑が 10以上ある場合には全例が高血圧を生じて括り, 高血圧 例で血圧の上昇が偏腎性であるか否かを判定する方法と して，JGIや JGCC とならんで採用しらるのではな いかと考㝋られる。

\section{VI. 結 語}

1. 60 羽の成熟家躳を用い, 一側腎動脈狭窄手術を施 行し, 狭窄度と狭窄後経過日数との穾験条件を組合わせ て, 各実験条件下における腎組織, なかんづく JGA の 態度を組織学的に研究した。

2. 腎動脈狭窄度の血圧に及ぼす影響に関しては，中 等度狭窄の場合高血圧発生例は64\%で最も高く, 次いで

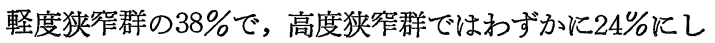
か認められなかつた。

3. JGA 以外の腎組織の変化については，狭窄によ る組織の障害は狭窄の程度に比例し, また障害は尿細管 飞最も早く出現し, 次いで系球体, 間質にも変化が及ぶ が，血管系の変化は最も遅れた．中小血管も含めて腎組 織の組織学的変化と高血圧発生との間に有意義な関係は 見られなかつた。

4. JGA は狭窄の 程度による影響もらけることを明 らかにした。すなわら狭窄が高度になると JG 細胞自体 も障害をこうむつて本来の機能を発揮しえなくなり，従 つて JGI などの index は適用できない.

5. JGA の狭窄処置後に抹惊逐時的変化を観察し， JGA が内分泌腺として期待される反応に適合した变化 を示すことを認めると同時に，JGI は狭窄後 1 週間よ り内分泌の指標となりらることを明らかにした。

6. JG 細胞の増生や肥大の程度を表わすために著者 の考案した IJGA は, 偏腎動脈狭窄による高血圧を判 定する指標として有用であることを証明した.

稿を終るに当り，終始御㤰篤な御指導並びに御校閲を 睗わつた恩師黒田恭一教授に束心より感謝の意を表わし ます：また御助言及び御協力を与えられた久住助教授, 津川講師及び教室員各位に深く感謝します。な政織学 的所見に関して御教示を戴いた第 2 病理学教室倉田助教 授, 及び J G 細胞顆粒の判定基準について御指導戴いた 長崎大学原子医学研究所西森教授飞謝意を表します。

本論文の要旨は第 54 回日本泌尿器科学会総会及び第 9 回日本腎臟学会総会に招いて発表した。
（本論交は金沢大学審査学位論文であることを付記す ๖.)

\section{文献}

1) Goldblatt, H. et al.: J. Exp. Med., 59, 347, 1934.

2) Goormaghtigh, N.: Proc. Soc. Exp. Biol. \& Med., 42, 688, 1939.

3) Tigerstedt, R. and Bergman, P.G.: Skand. Arch. f. Physiol., 8, 223, 1898.

4) Janeway, T.C.: Proc. Soc. Exp. Biol. \& Med., 6, 109, 1909.

5) Cash, J.R.: Bull. Johns Hopkins Hosp., 35, 168,1924.

6) Page, I.H.: Science, 89, 273, 1939.

7) Grollman, A.: Proc. Soc. Exp. Biol. \& Med., 57, 102,1944.

8) Hartwich, A.: Ztschr. f. ges. exp. Med., 69, $462,1930$.

9) Harrison, T.R. et al.: Trans. Assn. Am. Physiol., 51, 280, 1936.

10) Blalock, A. and Levy, S.E.: Ann. Surg., 106, 826, 1937.

11) Goldblatt, H. and Kahn, J.R.: J.A.M.A., 116, 2428, 1941.

12) Pedersen, A.H.: Arch. Path., 3, 912, 1927.

13) Bell, E.T. and Pedersen, A.H.: Ann. Int. Med., 4, 227, 1930.

14）後藤有司的：皮と泌，24，145, 昭37.

15) Hartman, F.W. et al.: Am. J. Med. Sci., $172,487,1926$ 。

16) Senator, H.: Z. Klin. Med, Berlin., 74, 297, 1912.

17) Cash, J.R.: Proc.Soc. Exp. Biol. \& Med., 23, 609, 1926.

18）坂本信有：長崎医誌，31，1044, 昭31.

19）渡辺昌平ら：日循誌，16，157, 昭 27 .

20) Masson, G.M.C. et al.: Arch. Path., 53,217, 1952.

21) Skelton, F.R.: Proc. Soc. Exp. Biol.\& Med., 90, 342,1955.

22) Goldblatt, H. et al.: Am. J. Path., 12, 760, 1936.

23) Braun-Menéndez, E. et al.: J. Physiol., 98, 283, 1940.

24) Page, I.H. et al.: Am. Heart J., 1940.

25）杉山繁輝：日微会誌，18，527, 大13.

26) Ruyter, J.H.C.: Ztschr. f. Zellforsch. u. mikr. Anat., 2, 242, 1925.

27) Oberling, C.: Compt. rend. Acad. Sci., 187, 1200, 1927.

28) Okkels, H.: Bull. Histol. Techn. Micr., 6, $113,1929$. 
29) Goormaghtigh, N.: Arch. de. biol. Paris., $43,575,1932$.

30) Zimmermann, K.W.: Ztschr. f. mikr. anat. Forsch., 32, 176, 1933.

31) Becher, H.: Ztschr. f. wissensch. Mikr., 53, 205,1936 .

32) Oberling, C. and Hatt, P.Y.: Circulation Res., 12, 525, 1963. より引用

33）並木重郎ら：日泌尿会誌，36，27。昭18.

34) 原田澄：日泌尿会誌，43，236,昭27。

35）原田澄：日泌尿会誌，43，245, 昭27。

36）原田澄：日泌尿会誌，43，301, 昭27。

37) 原田澄。日泌尿会誌，43，348, 昭 27 .

38）原田澄：日泌尿会誌，43，421, 昭 27 。

39）原田澄：日泌尿会誌，44，26，昭 28.

40) Desprez, J.: Am. J. Clin. Path., 18, 953, 1948。

41) Kaufman, W.: Am. J. Path., 18, 783, 1942.

42) Latta, H. and Maunsbach, A.B.: J. Ultrast. Res., 6, 547, 1962.

43) Bowie, D.J. and Vineberg, A.M.: Quart. J. Exp. Physiol., 25, 247, 1935。

44) Hartroft, W.S. and Hartroft, P.M.: Fed. Proc., 20, 845, 1961.

45) 原田澄: 腎藏と旁系球体装置 (泌尿器科新書), 87 , 南江堂, 東京, 昭38。

46）江口季雄 : 日本臨床, 18, 459, 昭35.

47) Hartroft, P.M. and Newmark, L.N.: Anat. Record., 139, 185, 1961.

48) Hartroft, P.M.: Circulation Res., 12, 525, 1963.

49) Barajas, L. and Latta, $H_{\circ}$ : Lab. Invest., 12 : $257,1963$.

50) Kroon, D.B.: Acta Anat., 41, 138, 1960.

51) Stone, R.S. et al.: Arch. Path., 71, 160, 1961.

52) Bucher, O. and Reale, E.: Ztschr. f. Zellforsch u. mikr. Anat., 54, 167, 1961.

53) Hartroft, P.M. and Hartroft, W.S.: J. Exp. Med., 97, 415, 1953.

54) Dunihue, F.W. and Candon, B.H.: Arch. Path., 29, 777, 1940.

55) Graef, I.: Am. J. Path., 19, 121, 1943.

56) Tobian, L. et al.: Proc. Soc. Exp. Biol. \& Med., 100, 94, 1959.

57) Tobian, L.: J. Lab. \& Clin. Med., 54, 951, 1959.

58) Pitcock, J.A. et al.: Proc. Soc. Exp. Biol. \& Med., 100, 868, 1959.

59) Pitcock, J.A. and Hartroft, P.M.: Fed. Proc., 18, 500, 1959.

60) Janacek, J. et al.: Fed. Proc., 19, 100,1960。

61) Fisher, E.R. et al.: Proc. Soc. Exp. Biol. \& Med., 118, 1191, 1965.
62) Newmark, L.N. et al.: Anat. Record., 133, 316,1959 。

63) Kuhn, C. et al.: Fed. Proc., 20, 404, 1961.

64) Cook, W.F. and Pickering, G.W.: J. Physiol., 143, 78, 1958 .

65) Cook, W.F. and Pickering, G.W.: J. Physiol., 149, 526, 1959.

66) Cook, W.F.: J. Physiol., 152, 27, 1960.

67) Bing, J. and Wiberg, B.: Acta Path. et Microbiol. Scand., 44, 138,1958.

68) Bing, J. and Kazimicrczak, J.: Acta Path. et Microbiol. Scand., 47, 105, 1959.

69) Bing, J. and Kazimierczak, J.: Acta Path. et Microbiol. Scand., 50, 1,1960.

70) Bing, J. and Kazimierczak, J.: Acta Path. et Microbiol. Scand., 54, 80, 1962.

71) Brown, J.J. et al.: J. Physiol., 176, 418, 1965.

72) Friedman, M. and Kaplan, A.: J. Exp. Med., 76, 307,1942.

73) Friedman, M. and Kaplan, A.: J. Exp. Med., 77, 65, 1943.

74) Yoshimura, F. and Negishi, A.: Am. J. Physiol., 178, 251, 1954.

75) Dempoulos, H. et al.; Am. J. Path., 37, 443, 1960.

76) Vikhert, A.M. and Serebrovskaya, Y.A.: Fed. Proc., 23, 178, 1964.

77) Edelman, R. and Hartroft, P.M.: Circulation Res., 9, 1069, 1961.

78) Hartroft, P.M. and Hartroft, W.S.: Canad, Med. Ass. J., 90, 163, 1961.

79) Hess, R. and Pearse, A.G.E.: Brit. J. Exp. Path., 40, 243, 1959.

80) Hess, R. and Gross, F.: Am. J. Physiol., 197, 869, 1959.

81) Hess, R. and Regoli,D.: Brit. J. Exp. Path., 45, 6,1964。

82) Fisher, E.R.: Fed. Proc., 20, 404, 1961.

83) Dunihue, F.W.: Am. J. Path., 23, 906, 1947.

84) Hartroft, P.M. and Hartroft, W.S.: J. Exp. Med., 102, 205,1955。

85) Tobian, L. et al.; J. Clin. Invest., 38, 605, 1959.

86) Goormaghtigh, N.: Am. J. Path., 23, 513, 1947.

87) Dunihue, F.W. and Robortson, W.V.: Endocrinology, 61, 293,1957.

88) Tobian, L. et al。 J. Lab. \& Clin. Med., $53,842,1959$ 。

89) 西森一正ら：日病会誌，50，258, 昭36。

90) 小林快三ら：日循誌，25，664, 昭36。

91）賀来交雄：長崎医誌，38，287, 昭38。

92) Pitcock, A.J. and Hartroft, P.M.: Am. J. 
Path., 34, 863, 1958.

93) Hartroft, P.M. and Hathway, S.D.; Fed. Proc., 23, 445, 1964.

94) Fisher, E.R. and Klein, H.Z.: Proc. Soc. Exp. Biol. \& Med., 113,317, 1963.

95) Torikai, T.: Tohoku J. Exp. Med., 82, 74, 1964.

96) Marks, B.H. et al: Proc. Soc. Exp. Biol. \& Med., 105, 593, 1960.

97) Tobian, L.: Ann. Int. Med., 52, 395, 1960.

98) Tobian, L. et al: Ann. Int. Med., 57, 382, 1962.

99) Tobian, L.: Canad. Med. Ass. J., 90, 160, 1964.

100) Skinner, S.L. et al: Science, 140, 30, 1963.

101) Skinner, S.L. et al: Science, 141, 814, 1963.

102) Shipley, R.E. and Study, R.S.: Am. J. Physiol., 167, 676, 1951.

103) Stahl, W.H.: Ann. Surg., 160, 958, 1964.

104) Tribe, C.R. and Heptinstall, R.H.; Brit. J. Exp. Path., 46, 339, 1965.

105) Hartroft, P.M.: J. Exp. Med., 105, 501, 1957.

106) Tobian, L. et al: J. Clin. Invest., 37, 660, 1958.

107）大城浩 : 京都医誌, 40, 1541, 昭 18.

108）大城浩 : 京都医誌, 40, 1551, 昭 18.

109）大城浩 : 京都医誌, 40, 1637, 昭 18.

110) 大城浩 : 京都医誌, 40, 1643, 昭18.

111）大城浩 : 京都医誌, 40, 1651, 昭18.

112) Turgeon, C. and Sommers. S.C.: Fed. Proc., 19, 361, 1961.

113) Turgeon, C. and Sommers, S.C.: Am. J. Path., 38, 227, 1961.

114) Crocker, D.W. et al; New Eng. J. Med., 267, 794, 1962.

115) Boughton, R:M. and Sommers, S.C.: J. Urol., 89, 133,1963.

116) 織田春一：十全会誌, 57, 1900, 昭30.

117) Itskovitz, H.D. et al.: Ann. Int. Med., 59, 8,1963 .
118) Goldblatt, H.: J. Exp. Med., 67, 309, 1938.

119) Wilson, C. and Pickering, G.W.: Clin. Sci., 3, 343, 1937.

120）桂栄孝：長崎医誌，32，1138, 昭32.

121）亀山正邦：日循誌，21，641, 昭33,

112) Child, G.: J. Exp. Med., 67, 521, 1938.

123) Wilson, C. and Byrom, R.B.: Lancet, 1, 136, 1939.

124) Wilson, C. and Byrom, R.B.: Quart. J. Med., 10, 65, 1941.

125) 大島研三, 栗本東一：日循誌， $12 ， 74$, 昭 23 .

126）釾先行二ら：長崎医誌，42，461,昭 28.

127) Goldman, M.L. et al.: Am. J. Path., 28, $528,1952$.

128) Dammin, G.J. et al.: Am. J. Path., 31, 587, 1955.

129) Maier, N. et al.: Arch. Surg., 88, 113,1964.

130）前川孫二郎：日循誌，17，153, 昭 28 .

131）松永春二：長崎医誌, 35, 1139, 昭 35 .

132）池上奎一ら：皮と泌，23，3，昭36.

133）宾戸仙太郎，夏目修：腎性高血圧症（新臨床医 学文庫), 金原出版, 東京, 昭40, p. 105.

134) Molitz, A.R. and Oldt, M.R.: Am. J. Path., 11, 885, 1935.

135) Molitz, A.R. and Oldt, M.R.: Am. J. Path., 13, 679, 1937.

136) 西森一正 : 最新医学, 18,1281 , 昭 38 .

137) 川口浩: 千葉医誌, 9,293, 昭 6 .

138) Bounous, G. and Schumacker, H.B.: Surgery, 52, 458, 1962 .

139) 池田正男: 最新医学, 18, 1270, 昭38.

140）石沢靖之：皮と泌，22，413, 昭35.

141) 太田康弘：皮と泌，26，970,昭39。

142) Miller, G. and Hartroft, P.M.: Fed. Proc., 20, 404, 1961.

143) Hirashima, K. and Takaku, F.: Blood, 20, 1, 1962.

144) Rapp, J.P.: Circulation, 206,93, 1964. (昭和41年11月19 日受付, 特別掲載) 